\title{
U.S. Building-Sector Energy Efficiency Potential
}

\author{
Rich Brown, Sam Borgeson, Jon Koomey, Peter Biermayer \\ ENVIRONMENTAL ENERGY TECHNOLOGIES DIVISION \\ Ernest Orlando Lawrence Berkeley National Laboratory \\ University of California \\ Berkeley, California 94720
}

September 2008

This work was supported by the U.S. Environmental Protection Agency, Climate Protection Partnerships Division, Office of Air and Radiation, under U.S. Department of Energy Contract No. DE-AC02-05CH11231. 


\section{DISCLAIMER}

This document was prepared as an account of work sponsored by the United States Government. While this document is believed to contain correct information, neither the United States Government nor any agency thereof, nor The Regents of the University of California, nor any of their employees, makes any warranty, express or implied, or assumes any legal responsibility for the accuracy, completeness, or usefulness of any information, apparatus, product, or process disclosed, or represents that its use would not infringe privately owned rights. Reference herein to any specific commercial product, process, or service by its trade name, trademark, manufacturer, or otherwise, does not necessarily constitute or imply its endorsement, recommendation, or favoring by the United States Government or any agency thereof, or The Regents of the University of California. The views and opinions of authors expressed herein do not necessarily state or reflect those of the United States Government or any agency thereof or The Regents of the University of California.

This work was supported by the U.S. Environmental Protection Agency, Climate Protection Partnerships Division, Office of Air and Radiation, under U.S. Department of Energy Contract No. DE-AC02-05CH11231. 


\section{Abstract}

This paper presents an estimate of the potential for energy efficiency improvements in the U.S. building sector by 2030. The analysis uses the Energy Information Administration's AEO 2007 Reference Case as a business-as-usual (BAU) scenario, and applies percentage savings estimates by end use drawn from several prior efficiency potential studies. These prior studies include the U.S. Department of Energy's Scenarios for a Clean Energy Future (CEF) study and a recent study of natural gas savings potential in New York state. For a few end uses for which savings estimates are not readily available, the LBNL study team compiled technical data to estimate savings percentages and costs of conserved energy. The analysis shows that for electricity use in buildings, approximately one-third of the BAU consumption can be saved at a cost of conserved energy of $2.7 \varnothing / \mathrm{kWh}$ (all values in 2007 dollars), while for natural gas approximately the same percentage savings is possible at a cost of between 2.5 and 6.9 \$/million Btu ( 2.4 to $6.6 \$ / \mathrm{GJ})$. This cost-effective level of savings results in national annual energy bill savings in 2030 of nearly $\$ 170$ billion. To achieve these savings, the cumulative capital investment needed between 2010 and 2030 is about $\$ 440$ billion, which translates to a $2-1 / 2$ year simple payback period, or savings over the life of the measures that are nearly 3.5 times larger than the investment required (i.e., a benefit-cost ratio of 3.5). 


\section{Acknowledgements}

This work was supported by the U.S. Environmental Protection Agency, Climate Protection Partnerships Division, Office of Air and Radiation, under U.S. Department of Energy Contract No. DE-AC02-05CH11231.

We would like to thank Howard Geller, David Goldstein, and Art Rosenfeld — members of the Building-sector energy efficiency subcommittee of the National Academy of Engineering's study on America's Energy Future. They played a significant role in inviting LBNL's involvement and defining the scope of this study, as well as providing extensive input on methodology and presentation of results. We thank Kathleen Hogan and Joe Bryson of U.S. EPA/CPPD for funding this study. 


\section{Introduction}

The goal of this analysis is to estimate the potential for energy efficiency improvements in the U.S. building sector by 2030, to inform the study on America's Energy Future being conducted by the National Academy of Engineering. ${ }^{1}$

The output of the study is a techno-economic potential for energy savings, which includes costeffectiveness criteria but ignores the effect of policy implementation. Results are expressed in terms of cost of conserved kWh of electricity and million Btus of natural gas.

\section{Methodology and Data}

\section{Business-As-Usual Forecast}

This analysis starts with the Energy Information Administration's Annual Energy Outlook (AEO) 2007 Reference Case as business-as-usual (BAU) scenario, segmented by fuel and end use (US DOE 2007b). ${ }^{2}$ We adjusted the published AEO end use consumption values in 2030 to allocate some of the consumption in the "Other Uses" end use (mainly cooking and electronics) to the traditional end uses where it appropriately belongs. This re-allocation was based on data published by the Department of Energy (US DOE 2007a). ${ }^{3}$ Tables 1 and 2 show the revised AEO Reference Case that is used here as the BAU scenario, presented in terms of site energy. We only consider electricity and natural gas in this analysis. These forms of energy account for about $92 \%$ of primary energy use in U.S. buildings.

The BAU scenario, which includes some level of energy efficiency improvement driven by market forces as well as codes and standards, assumes that residential electricity use increases $1.4 \%$ per year and that commercial electricity use increases $1.9 \%$ per year on average during 2006-2030. For comparison, residential electricity use increased $2.4 \%$ per year and commercial use $2.8 \%$ per year on average during 1990-2006 (US DOE 2007c). With respect to natural gas use, the BAU scenario assumes growth rates of $0.8 \%$ per year in the residential sector and $1.6 \%$ per year in the commercial sector during 2006-2030.

\section{Savings Potential and Cost-effectiveness}

To calculate cost-effective energy savings potential in 2030, we compiled percentage savings estimates by end use, drawn from several prior studies, and applied these to the BAU scenario described above. For most end uses, the Scenarios for a Clean Energy Future (CEF) study was used to estimate savings potential (Interlaboratory Working Group on Energy-Efficient and Clean-Energy Technologies 2000, Koomey et al. 2001). For the residential natural gas end uses, we used savings estimates from a recent study of natural gas savings potential in New York state (Mosenthal et al. 2006). For selected end uses that were not analyzed in the CEF study, we

\footnotetext{
${ }^{1}$ See http://www8.nationalacademies.org/cp/projectview.aspx?key=48844.

${ }^{2}$ Although a preliminary version of the AEO 2008 was available, a revised version was being prepared to include the effects of the recently passed 2007 Energy Independence and Security Act (EISA); full documentation for this revised version was not available in time to incorporate here.

${ }^{3}$ The "adjust to SEDS" calibration factor contained in the AEO "Other Uses" end use was also allocated proportionally to each of the other end uses, according to their relative share of 2005 consumption.
} 
compiled technical data to estimate savings percentages and costs of conserved energy. The specific data source used for each end use is identified in Tables 1 and 2. Each of these studies is described in more detail below.

To provide a better sense of the technologies that were used to estimate these potentials, Tables 3 and 4 list the principal technologies or efficiency improvement assumptions used for each end use. For the most part the technologies are widely available in the marketplace and well proven as of 2008. A few of the technologies such as heat pump water heaters are still produced on a limited scale and can be considered near-term emerging technologies.

Table 1: Summary of residential buildings consumption, savings potential and measure costs in 2030, by end use

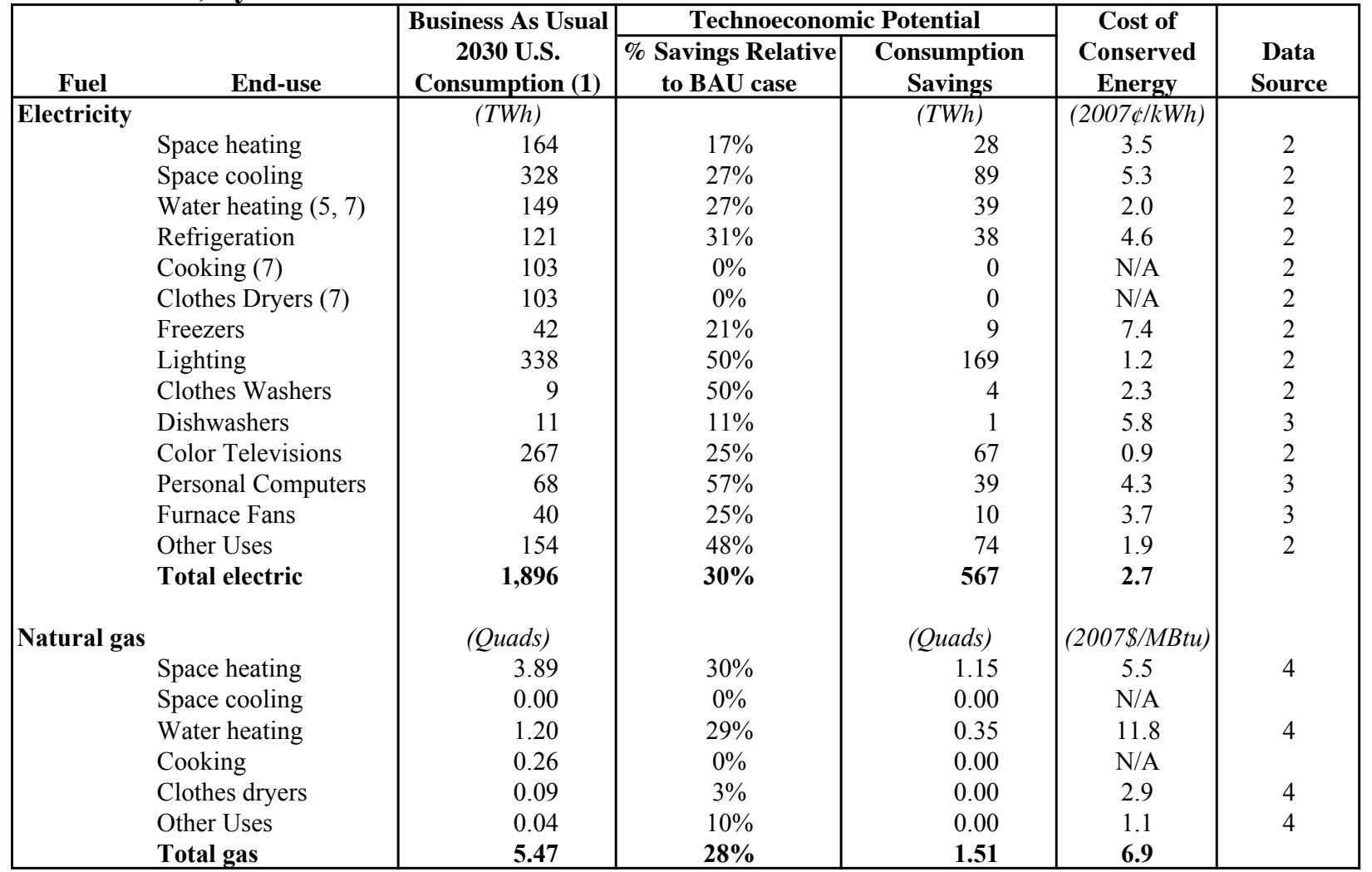

(1) 2007 AEO reference case end use consumption for the "Other" end use was re-allocated to match the 2007 DOE Buildings Energy Databook (US DOE 2007a) end use shares, and the "adjust to SEDS" calibration value was allocated proportionally to each end use rather than lumped into the "Other" end use.

(2) Source for potential savings and CCE is the CEF study Table D-1.1 (Interlaboratory Working Group on EnergyEfficient and Clean-Energy Technologies 2000). CCEs are from the CEF Advanced Case; calculated using a real discount rate of $7 \%$ and lifetimes as shown in CEF report Appendix C-1.

(3) Source for potential savings and CCE is the LBNL analysis documented in Tables 5 and 6.

(4) Source for potential savings and CCE is the New York State natural gas potential study (Mosenthal et al. 2006).

(5) CCE for electric water heating was incorrect in the original CEF report and has been corrected here.

(6) End uses with costs of conserved energy listed as N/A were not analyzed in this study.

(7) CEF results were adjusted to remove fuel switching (electric to gas) as a measure for water heaters, cooking and clothes dryers.

(8) Consumption and CCEs are based on site energy. 
Table 2: Summary of commercial buildings consumption, savings potential and measure costs in 2030, by end use

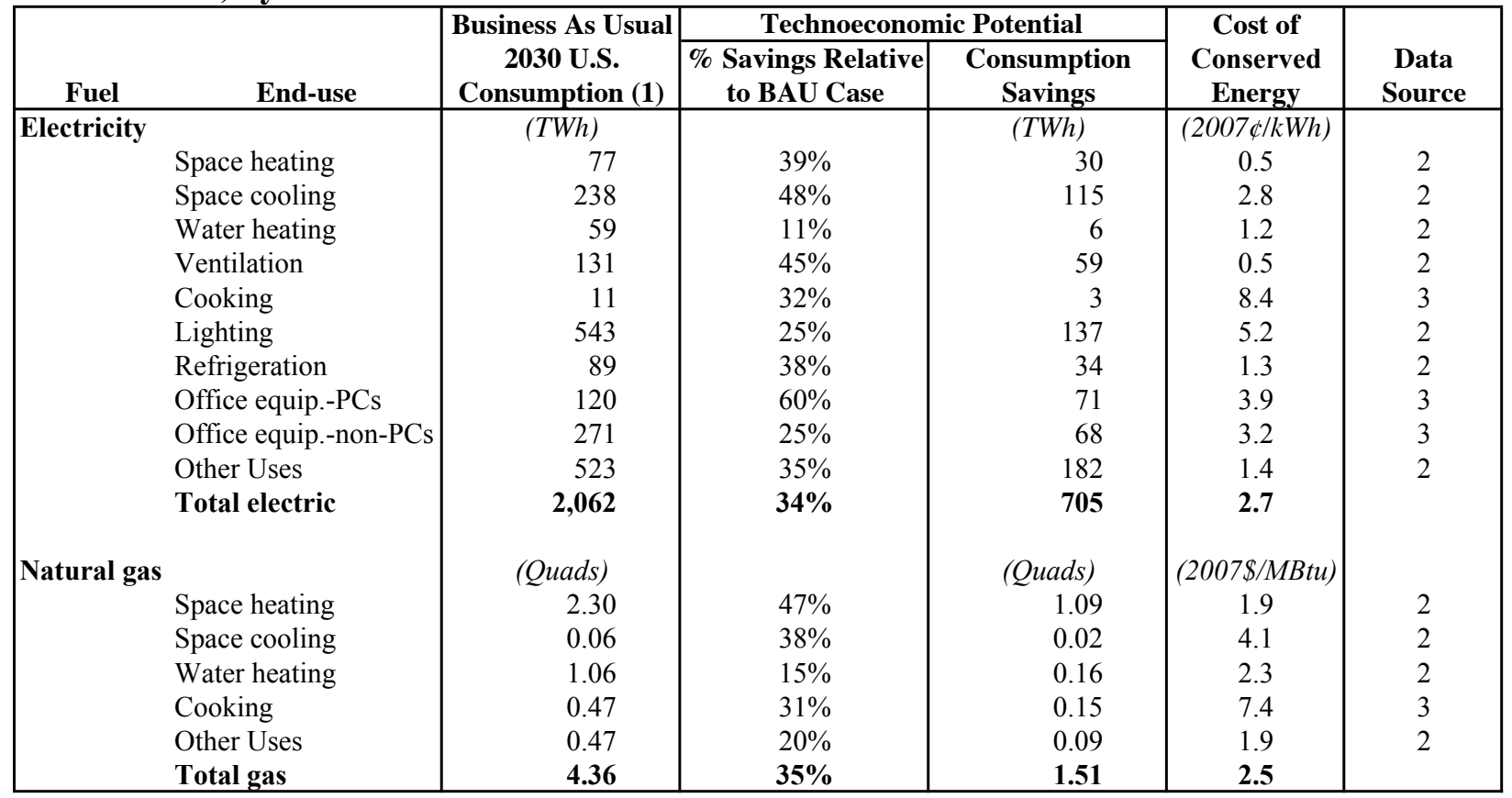

(1) AEO reference case end use consumption for the "Other" end use was re-allocated to match the 2007 DOE Buildings Energy Databook (US DOE 2007a) end use shares, and the "adjust to SEDS" calibration value was allocated proportionally to each end use rather than lumped into the "Other" end use.

(2) Source for potential savings and CCE is the CEF study Table D-1.1 (Interlaboratory Working Group on EnergyEfficient and Clean-Energy Technologies 2000). CCEs are from the CEF Advanced Case; calculated using a real discount rate of $7 \%$ and lifetimes as shown in CEF report Appendix C-1.

(3) Source for potential savings and CCE is the LBNL analysis documented in Tables 5 and 6.

(4) Consumption and CCEs are based on site energy.

To estimate aggregate savings potential in 2030, we multiplied the energy savings potential shown by end use in Tables 1 and 2 by the estimates of energy consumption by end use in the BAU scenario. The cost of conserved energy (CCE) is the levelized annual cost of the efficiency measures over their lifetime divided by the estimated annual energy savings. The CCE accounts for incremental measure costs only; no cost is assumed for policies or programs aimed at stimulating measure adoption. Consistent with the CEF study, a real discount rate of $7 \%$ was used to calculate these values. Cost of conserved energy values from the CEF and New York state studies were inflated to 2007 dollars using the GDP implicit price deflator (BEA 2008). 
Table 3: Residential building measures included in efficiency potential studies used for this analysis

\begin{tabular}{|c|c|c|}
\hline Fuel & End-use & Efficiency measure description \\
\hline \multicolumn{3}{|l|}{ Electricity } \\
\hline & Thermal shell & $\begin{array}{l}\text { Existing electric-heated homes: no efficiency measures; New homes: up to } \\
40 \% \text { savings compared to } 2006 \text { IECC }\end{array}$ \\
\hline & Space heating equipment & Switch electric furnace to heat pump, improved heat pump efficiency \\
\hline & Space cooling equipment & $\begin{array}{l}\text { Improved efficiency central and room air conditioners, variable speed } \\
\text { RAC }\end{array}$ \\
\hline & Water heating & $\begin{array}{l}\text { Reduced standby-loss electric resistance water heater, heat pump water } \\
\text { heater, horizontal axis clothes washer }\end{array}$ \\
\hline & Refrigeration & Best-in-class Energy Star refrigerator, 2008 \\
\hline & Freezers & Best-in-class Energy Star freezer, 2008 \\
\hline & Lighting & Compact fluorescent fixtures, Halogen infrared lamps, Reduced wattage \\
\hline & Clothes washers & Horizontal axis washer with improved motor \\
\hline & Dishwashers & Dishwasher with improved pump design and improved motor \\
\hline & Color televisions & Reduced standby power use \\
\hline & Personal computers & Energy Star-rated PC and monitor, power-management enabled \\
\hline & Furnace fans & Electronically commutated permanent magnet furnace-fan motor, single- \\
\hline & Other uses & More efficient motors in ceiling fans, pool pumps and other small motors; \\
\hline \multicolumn{3}{|l|}{ Natural gas } \\
\hline & Thermal shell & $\begin{array}{l}\text { Air sealing, R-19 floor insulation, R-21 wall insulation, R-49 attic } \\
\text { insulation, Integrated design for new construction (SF } 30 \%>\text { code, MF } \\
50 \%>\text { code), Triple-pane low-e windows, Insulated attic hatch }\end{array}$ \\
\hline & Space heating equipment & Insulate/seal/balance ducts, Place ducts within thermal shell, Condensing \\
\hline & Space cooling equipment & N/A \\
\hline & Water heating & $\begin{array}{l}\text { On-demand water heater, } 0.63 \text { EF gas water heater, low-flow plumbing } \\
\text { fittings, Energy Star clothes washer, Reduced WH tank temp., Graywater } \\
\text { heat exchanger/GFX, Pipe insulation }\end{array}$ \\
\hline & Cooking & N/A \\
\hline & Clothes dryers & Humidity sensor control \\
\hline & Other uses & Pool and spa covers \\
\hline
\end{tabular}


Table 4: Commercial building measures included in efficiency potential studies used for this analysis

\begin{tabular}{|c|c|c|}
\hline Fuel & End-use & Efficiency measure description \\
\hline \multicolumn{3}{|c|}{ Electricity } \\
\hline & Thermal shell & No efficiency measures \\
\hline & Space heating equipment & $\begin{array}{l}\text { Up to } 55 \% \text { savings in existing buildings from improved HVAC equipment } \\
\text { and controls }\end{array}$ \\
\hline & Space cooling equipment & $\begin{array}{l}\text { Up to } 55 \% \text { savings in existing buildings from improved HVAC equipment } \\
\text { and controls }\end{array}$ \\
\hline & Water heating & $20 \%$ savings compared to frozen efficiency baseline \\
\hline & Ventilation & $\begin{array}{l}\text { Up to } 55 \% \text { savings in existing buildings from improved shell, HVAC } \\
\text { equipment and controls }\end{array}$ \\
\hline & Cooking & Energy Star-rated dishwasher, fryer, hot food holding cabinet, and \\
\hline & Lighting & $\begin{array}{l}\text { T-8 lamps and electronic ballasts; } 32 \% \text { combined savings from occupancy } \\
\text { controls, daylight dimming, and improved lighting design }\end{array}$ \\
\hline & Refrigeration & $20 \%$ to $45 \%$ savings compared to frozen efficiency baseline \\
\hline & Office equip.-PCs & Energy Star-rated PC and monitor, power-management enabling software \\
\hline & Office equip.-non-PCs & Energy Star-rated copiers and printers \\
\hline & Other Uses & More efficient motors in ceiling fans, pool pumps and other small motors; \\
\hline \multicolumn{3}{|c|}{ Natural gas } \\
\hline & Thermal shell & No efficiency measures \\
\hline & Space heating equipment & $\begin{array}{l}\text { Up to } 55 \% \text { savings in existing buildings from improved shell, HVAC } \\
\text { equipment and controls }\end{array}$ \\
\hline & Space cooling equipment & $\begin{array}{l}\text { Up to } 55 \% \text { savings in existing buildings from improved shell, HVAC } \\
\text { equipment and controls }\end{array}$ \\
\hline & Water heating & $10 \%$ savings compared to frozen efficiency baseline \\
\hline & Cooking & $\begin{array}{l}\text { Energy Star-rated fryer and steamer; more efficient broilers, griddles and } \\
\text { ovens }\end{array}$ \\
\hline & Other Uses & $10 \%$ reduction in miscellaneous gas use; Up to $55 \%$ reduction in district \\
\hline
\end{tabular}

\section{Scenarios for a Clean Energy Future Study}

The CEF study contains detailed end use technology data and savings potential over the 2000 to 2020 time period. ${ }^{4}$ Tables 1 and 2 list these values and the associated CCE for each end use. Technology costs were drawn from the CEF "Advanced" case, which assumed a greater penetration of more advanced efficiency technologies. While the CEF study also defined policy pathways to implement these technologies (Koomey et al. 2001), we only make use of the technoeconomic potentials it reported. Those savings potentials are based on a "phased-in" approach, which explicitly accounts for stock turnover using retirement functions for buildings and equipment. ${ }^{5}$ This approach gives the most realistic picture of potential energy savings in the face of real limits on how fast the capital stock is replaced, and assumes no early replacement of equipment before its economic lifetime.

\footnotetext{
${ }^{4}$ Results of the spreadsheet analysis are drawn from Appendix D-1 of the CEF report (Interlaboratory Working Group on Energy-Efficient and Clean-Energy Technologies 2000). These results differ slightly from the "final" integrated CEF results derived from energy sector-wide runs of the National Energy Modeling System (NEMS) forecasting model, which include the effect of energy supply and price feedbacks.

${ }^{5}$ Although, as Tables 3 and 4 indicate, CEF did not include thermal shell retrofits for most types of existing buildings.
} 
In using the CEF savings potentials to estimate the national savings potential in 2030, we assume that the CEF savings potential estimated for 2000-2020 would still be applicable for the 20102030 period. While some efficiency measures such as compact fluorescent lamps, more efficient lighting devices for commercial buildings, and Energy Star personal computers and other electronic devices have already been adopted to a significant degree, new efficiency measures have entered the marketplace since 2000 and others are under development and expected to be commercialized in the near future. This effect is probably best illustrated with residential central air conditioners (CAC). The CEF study assumed that the most efficient residential CAC had a seasonal energy efficiency ratio (SEER) of 18, which represented a significant savings potential compared to the minimum Federal standard of 10 SEER at that time. Since the CEF study was published, the minimum Federal standard has been increased to 13 SEER, which implies that a significant portion of the savings potential in the CEF study has been incorporated into today's baseline efficiency levels (and thus should not be "counted" in a savings potential analysis beginning in 2010). The most efficient products that are commercially available now, however, significantly exceed the efficiency of the best products available at the time of the CEF study. In fact, as of this writing there are over $30 \mathrm{CAC}$ models that are rated at higher than 18 SEER, and several that are rated at 23 SEER (CEE 2008). In addition, there now exist national standards for quality installation of heating and cooling systems, which help ensure that the potential savings from high-efficiency systems are actually realized in practice. For all these reasons, we believe that the improvements in the high-efficiency segment of the CAC market roughly compensate for the lost savings potential due to the increased Federal minimum standard, and this same pattern can be observed in other end uses as well. Thus, while today's energy efficiency baseline has improved somewhat since 2000, we assume that the number of efficiency technologies and practices yet to be adopted have kept pace with this improvement, keeping the overall efficiency potential roughly constant. Later in this report, we analyze changes in the AEO reference case to help assess whether this assumption is reasonable.

\section{New York State Natural Gas Savings Potential Study}

Because the CEF study did not model the savings potential of shell retrofits to existing homes, which resulted in unrealistically low savings potential for gas-heated homes, we instead used estimates of residential natural gas savings derived from a recent study of New York state (Mosenthal et al. 2006). The applicability of that study to the national context rests on the assumption that the percentage savings (relative to baseline consumption) in New York is representative of the country as a whole. The CCE, however, depends on the absolute consumption savings for a given measure, so we scaled the CCEs to account for heating degreeday differences between New York state and the national average. ${ }^{6}$ The CCEs were calculated using a 7\% discount rate, to be consistent with the other end uses in this analysis.

\section{LBNL Analysis of Additional End uses}

Several end uses were not analyzed in the CEF study, either due to lack of data or resources. These end uses are: commercial office equipment (both PCs and non-PCs), commercial cooking, residential office equipment, residential furnace fans, and residential dishwashers. For these end uses, we compiled technology performance and cost data and developed savings potential

\footnotetext{
${ }^{6}$ The potential savings estimates for "downstate" New York (New York City and its immediate environs) were used for this study. Adjusting to the national-average climate increased the CCEs by about $15 \%$ and was only applied to the space heating end use.
} 
estimates as part of this analysis. The details of these technology data are shown in Tables 5 and 6 , with detailed references provided in the notes to those tables. For the commercial and residential office equipment end uses, we primarily drew on information from the U.S. EPA Energy Star program and analysis performed by TIAX LLC for the U.S. Department of Energy (Roth et al. 2004, Roth et al. 2007). For the commercial cooking end use, the savings estimates are mainly based on information from the Energy Star program and the Food Service Technology Center (FSTC 2002). For residential furnace fans and dishwashers, we rely on data compiled for the U.S. Department of Energy's standards rulemakings for those products (Rosenquist et al. 2004, US DOE 2007d). 


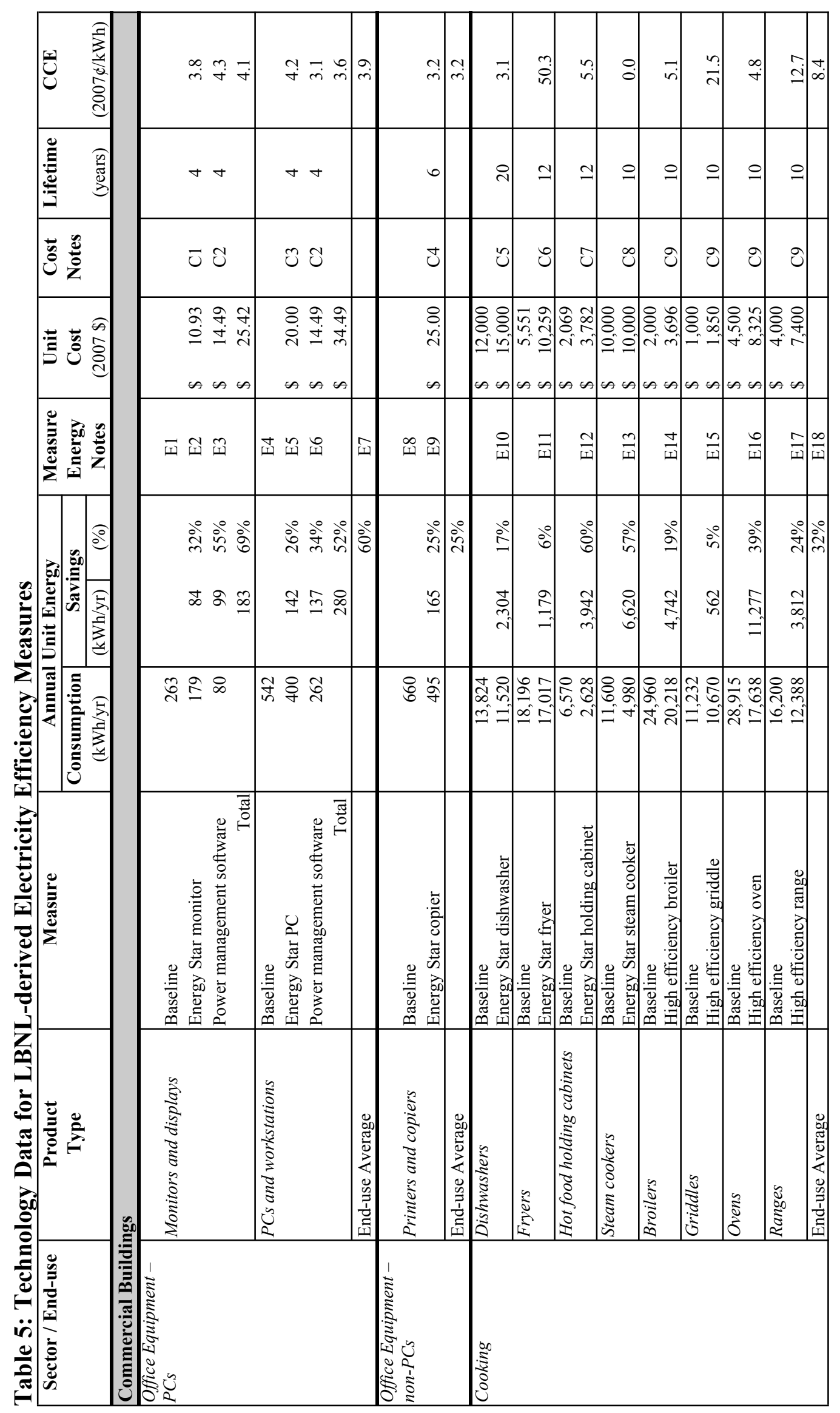



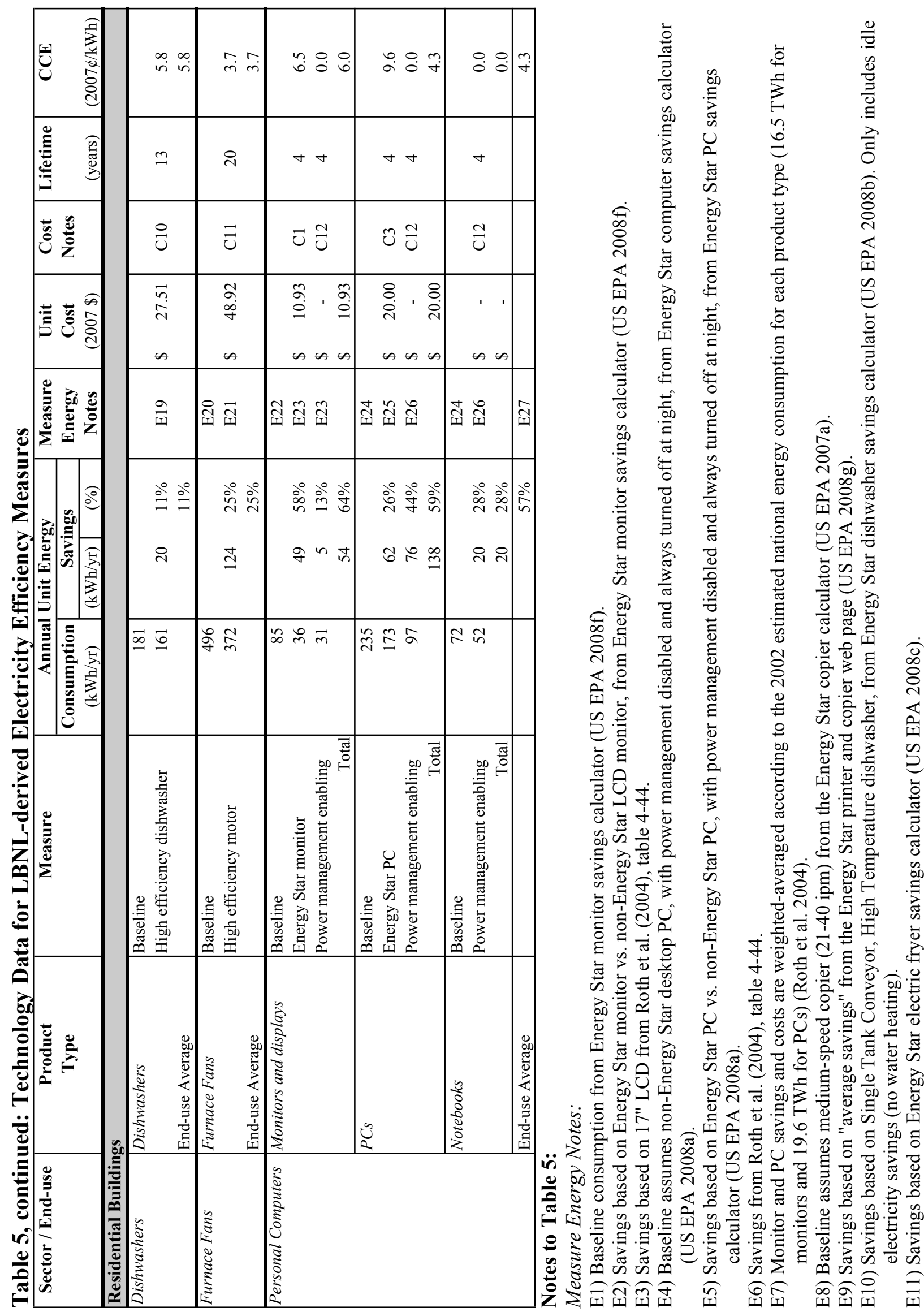


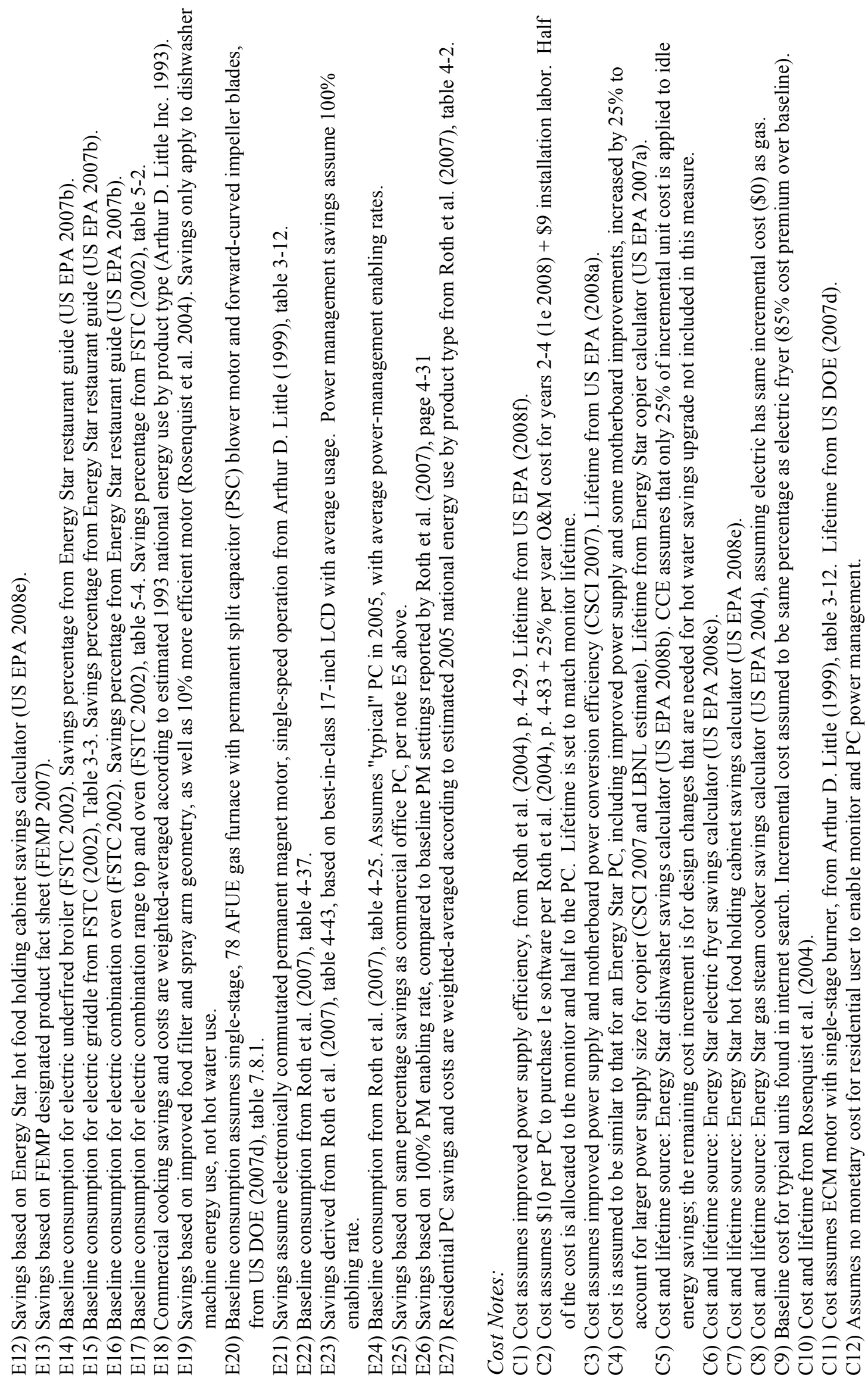



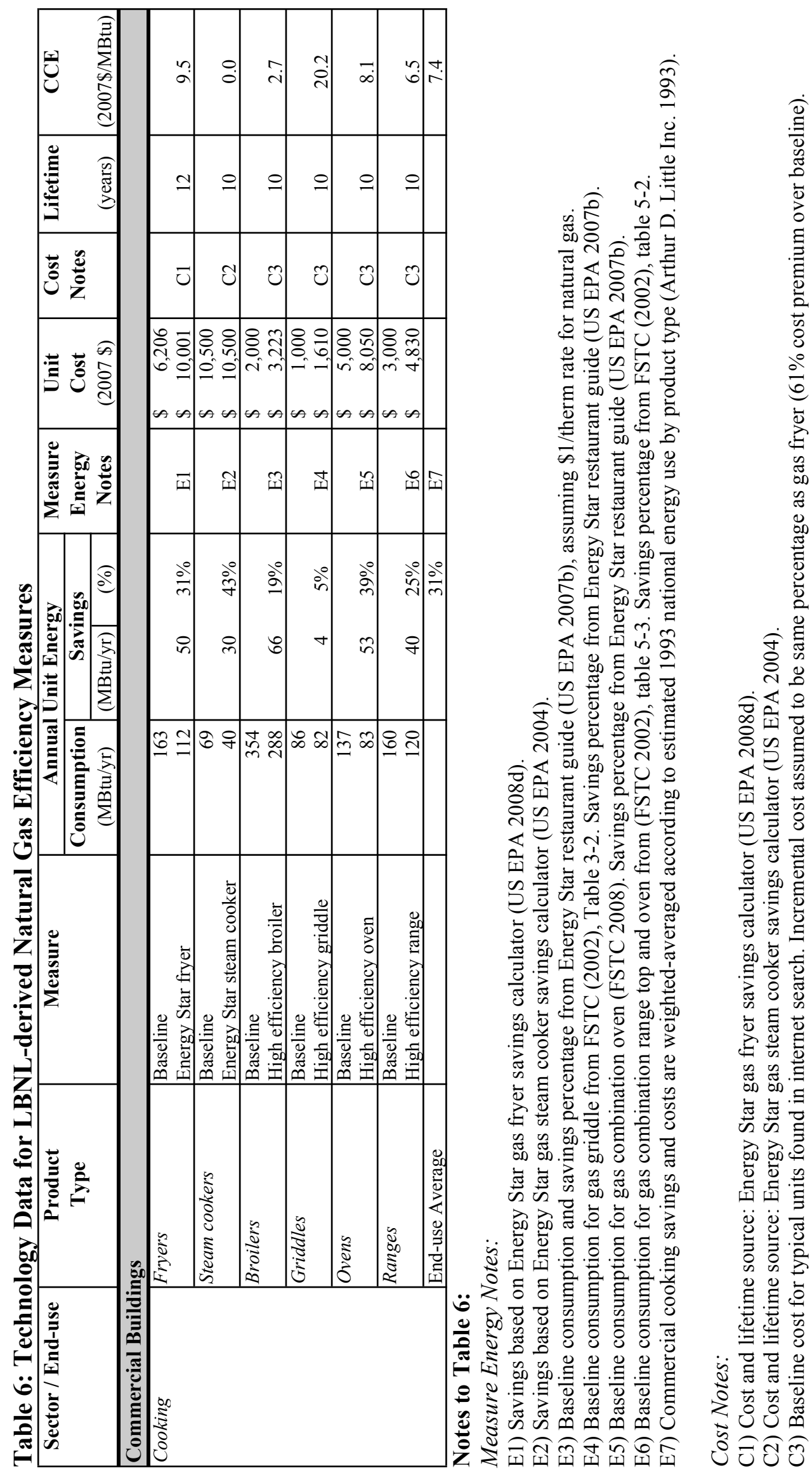


\section{Efficiency Supply Curves}

Figures 1 through 4 show the potential for energy efficiency improvements over the 2010-2030 period for the residential and commercial sectors, for electricity and natural gas. The $\mathrm{x}$-axis shows the total reduction in 2030 energy consumption, while the y-axis shows the CCE in fuelspecific units. Each step on the curve represents the total savings for a given end use for all the cost-effective efficiency measures analyzed for that end use. These are referred to as "supply curves" because they indicate how much energy savings is available for a given cost. The CCE is calculated as the savings-weighted average for all the measures in that end use cluster. End uses that do not have technology costs reported in Table 1 are not included in these plots (i.e., residential cooking and clothes dryers).

Each of the supply curves indicates that the projected BAU energy consumption in 2030 can be reduced by about $30 \%$ at a cost less than current retail energy prices. Table 7 compares the weighted-average cost of conserved energy from each supply curve to national average retail energy prices as of 2007. The data in the table show that the average cost of conserved energy is well below the retail energy price both fuels in both residential and commercial buildings, meaning that adopting efficiency measures is cost effective for households and businesses. Of course factors such as local energy prices and weather will influence cost effectiveness in any particular location.

Table 8 provides data about the aggregate costs and benefits of these efficiency technologies for the entire building sector. The cumulative capital investment needed between 2010 and 2030 is about $\$ 440$ billion, to achieve annual energy bill savings in 2030 of nearly $\$ 170$ billion. These savings result in a 2-1/2 year simple payback period, or savings over the life of the measures that are nearly 3.5 times larger than the investment required (i.e., a benefit-cost ratio of 3.5). 
Figure 1: Residential Electricity Savings Potential, 2030

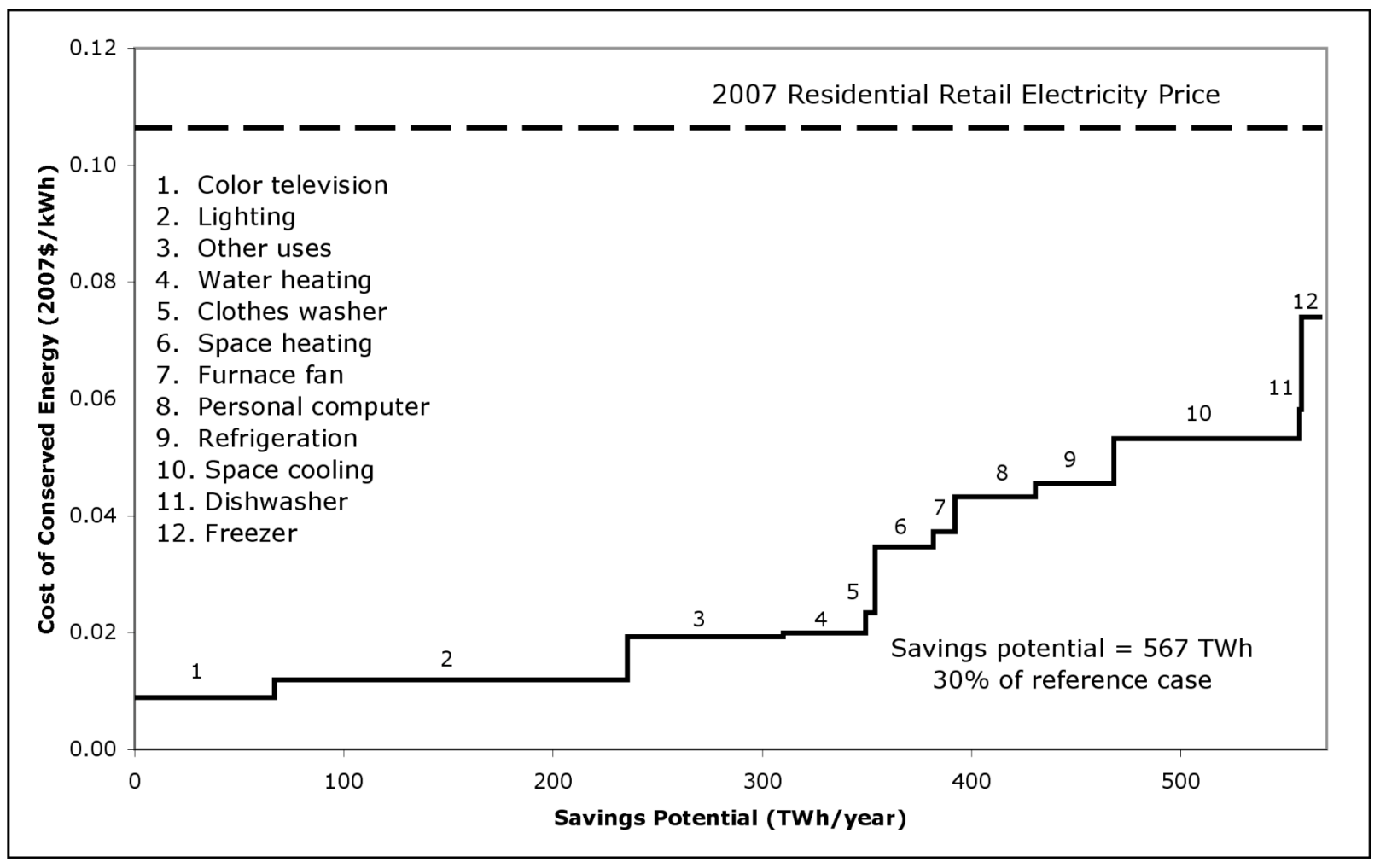

Figure 2: Residential Natural Gas Savings Potential, 2030

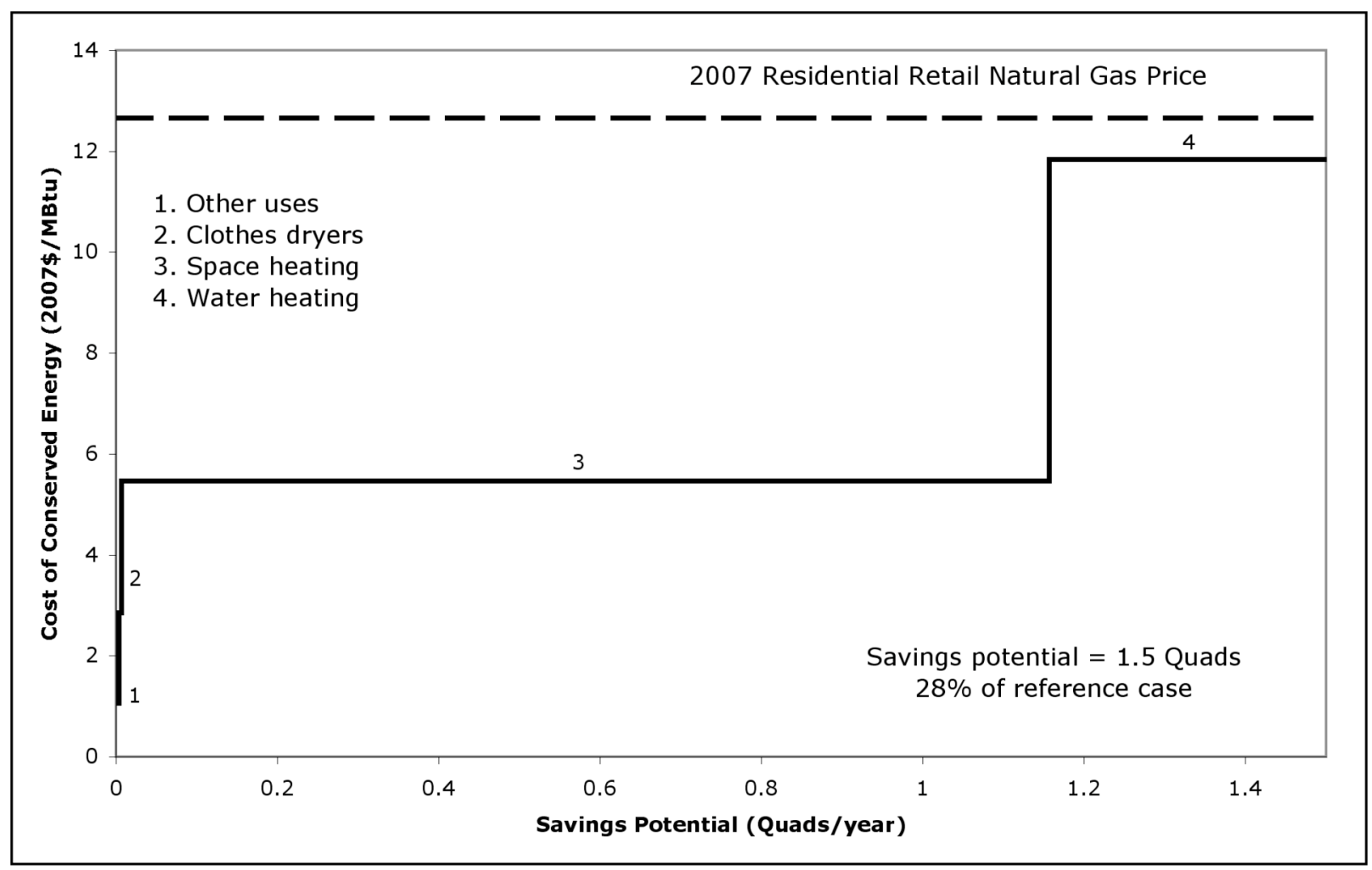


Figure 3: Commercial Electricity Savings Potential, 2030

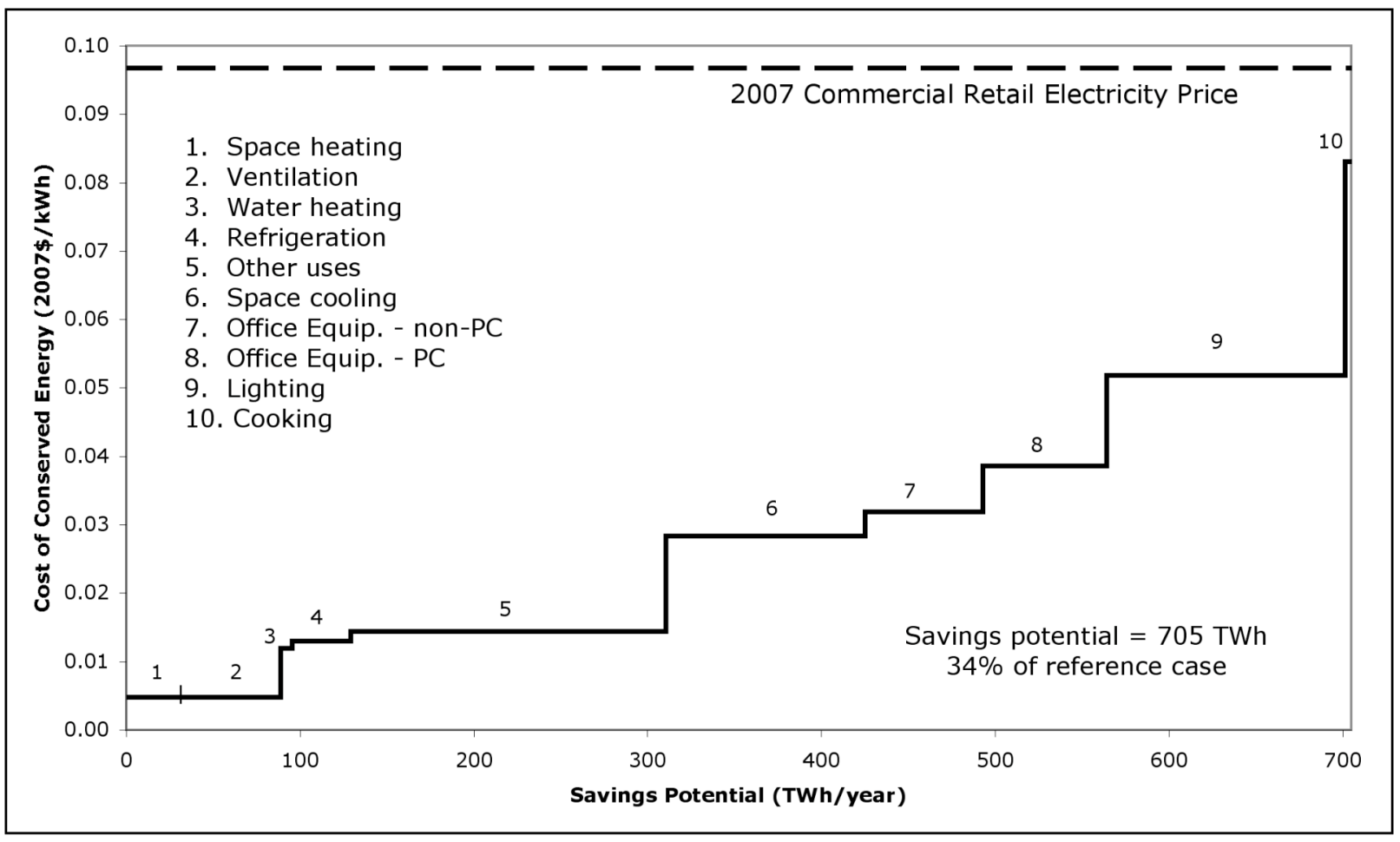

Figure 4: Commercial Natural Gas Savings Potential, 2030

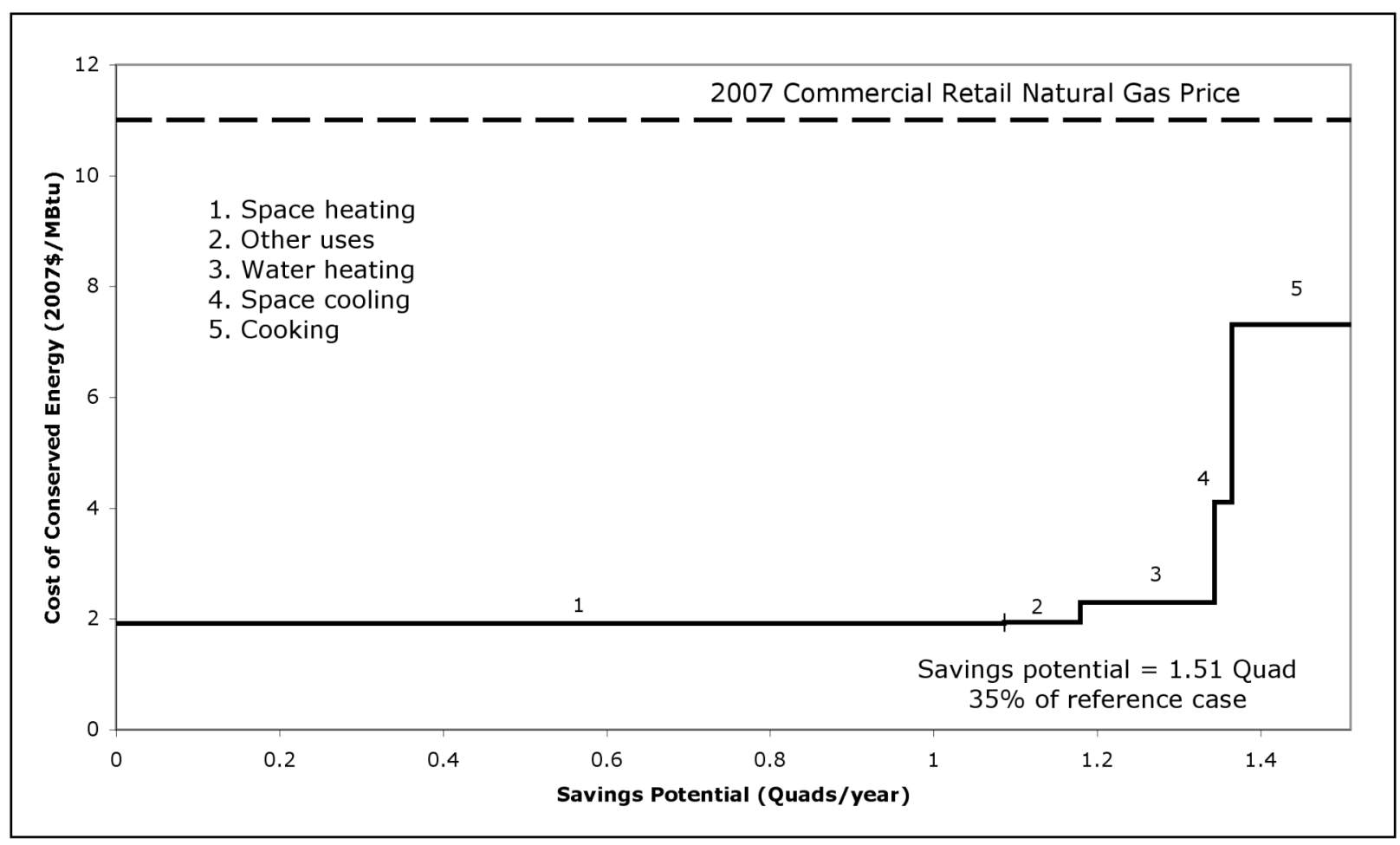


Table 7: Comparison of Average Cost of Conserved Energy and Retail Energy Prices

\begin{tabular}{|c|c|c|}
\hline $\begin{array}{c}\text { Sector and } \\
\text { Energy Type }\end{array}$ & $\begin{array}{c}\text { Average Cost of } \\
\text { Conserved Energy } \\
(\phi / k W h \text { or } \$ / M B t u)\end{array}$ & $\begin{array}{c}\text { National Average Retail } \\
\text { Energy Price (1) } \\
(\phi / k W h \text { or \$/MBtu })\end{array}$ \\
\hline Residential & 2.7 & 10.6 \\
Electricity & 6.9 & 12.7 \\
Natural Gas & & \\
Commercial & 2.7 & 9.7 \\
Electricity & 2.5 & 11.0 \\
Natural Gas & & \\
\hline
\end{tabular}

(1) Energy price data are 2007 national average values as reported by the Energy Information Administration (US DOE 2008).

Table 8: U.S. Efficiency Investment and Savings by 2030 (2007\$ billions)

\begin{tabular}{|c|c|c|c|}
\hline $\begin{array}{l}\text { Sector and } \\
\text { Energy Type }\end{array}$ & $\begin{array}{c}\text { Cumulative Capital } \\
\text { Investment }\end{array}$ & $\begin{array}{l}\text { Annual Utility Bill } \\
\text { Savings in } 2030(1) \\
\end{array}$ & \begin{tabular}{|c} 
Simple Payback \\
Time (years) \\
\end{tabular} \\
\hline Residential & & & \\
\hline Electricity & $\$ 136$ & $\$ 60$ & 2.3 \\
\hline Natural Gas & $\$ 104$ & $\$ 19$ & 5.5 \\
\hline Commercial & & & \\
\hline Electricity & $\$ 163$ & $\$ 68$ & 2.4 \\
\hline Natural Gas & $\$ 38$ & $\$ 17$ & 2.3 \\
\hline Total & $\$ 441$ & $\$ 164$ & 2.7 \\
\hline
\end{tabular}

(1) Assumes 2007 retail electricity and natural gas prices.

\section{Applicability of CEF Study to Estimate Current Potentials}

As discussed earlier, a key assumption in this analysis is that the CEF-reported percentage savings potentials in 2020 (measured from a base year of 2000) are still reasonable estimates of the potential remaining in 2030 (measured from a base year of 2010). In other words, we assume that energy efficiency is a "renewable" resource, in that any efficiency improvements realized in the last ten years have been replaced by new potential. Replacement of this efficiency potential can happen through introduction of new efficiency technologies, or through broader application of existing technologies.

As a simple test of this hypothesis, we compared forecasted energy intensities from the 1999 AEO (which served as the BAU case for the CEF study) and the 2007 AEO (which is the BAU case for this analysis) (US DOE 1998, US DOE 2007b). Figures 5 and 6 show these comparisons for the residential and commercial sectors, respectively. To account for changes in number and size of buildings in the stock, we normalized total energy consumption to the forecasted floor area of the building stock to calculate energy intensity. While energy intensity is influenced by 
many factors, including the saturation of energy-using devices and their intensity of use, improvements in efficiency should serve to reduce the energy intensity, and thus we use it as a rough proxy for changes in energy efficiency in buildings. Figure 5 shows that residential energy intensity is projected to decline at a similar rate in both the 1999 and 2007 AEO forecasts, which indicates that efficiency progress is assumed to be roughly similar in both forecasts. For the commercial sector, both AEO forecasts are essentially flat over the forecast period, indicating that the two forecasts are qualitatively similar (although the more recent AEO actually shows an increase in energy intensity, probably due to increased saturation of energy using devices). Based on these results, we believe that it is reasonable to assume that the magnitude of the savings potential estimated in CEF is still applicable today. For a more detailed analysis, Appendix A compares the two AEO forecasts at the end use level.

Figure 5: Comparison of Residential Energy Intensity Between AEO Forecasts

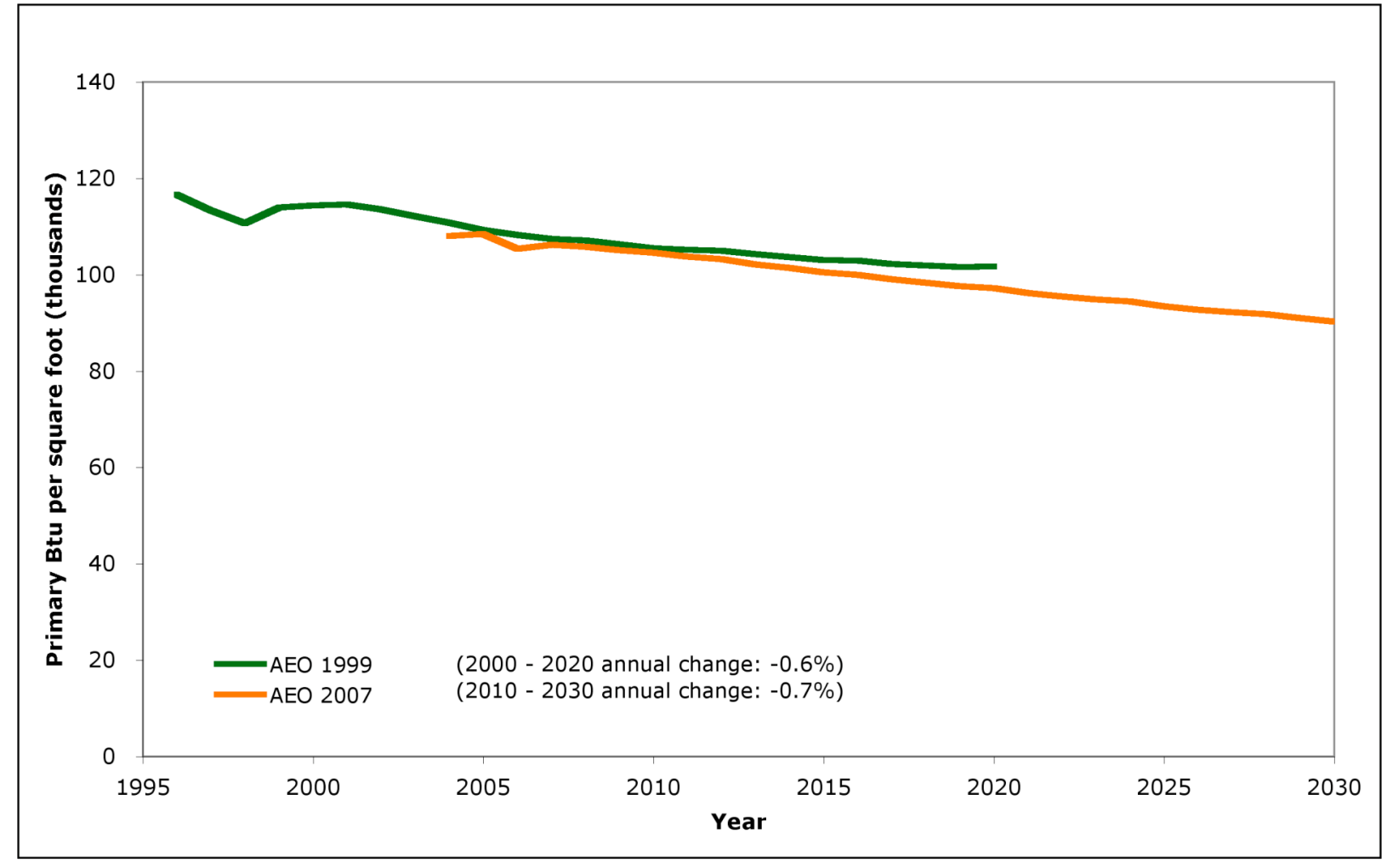


Figure 6: Comparison of Commercial Energy Intensity Between AEO Forecasts

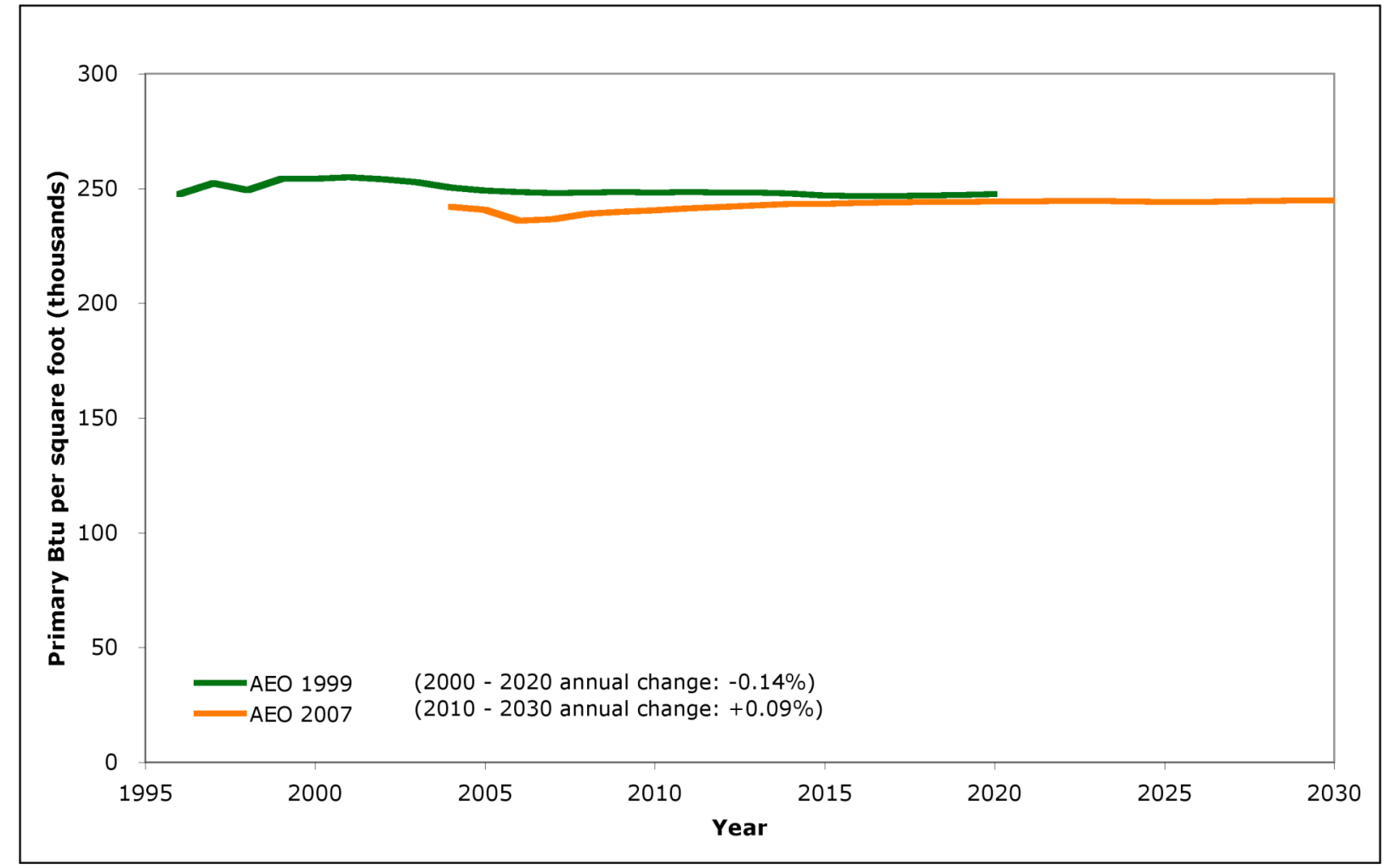

\section{Future Work}

Due to time and resource constraints, this analysis relied mainly on data from previous efficiency potential studies. An updated national savings potential analysis seems warranted, in order to inform programs and policies. The most recent study of this type was published by McKinsey and Company (Creyts et al. 2007). This study has received significant attention in the energy policy community, but the detailed inputs and assumptions used in the analysis have not been publicly documented, thus making it difficult to assess the accuracy and validity of its conclusions. An updated, peer-reviewed savings potential study could improve upon this study in several ways:

- The end use technology data used in this study are mostly drawn from the CEF study, which reflects technology and market conditions in the late 1990s. Clearly many factors have changed since then, including new technologies available in the market, changed prices due to increased sales volumes, improved manufacturing processes, transitions to low-cost manufacturing countries, etc. For example, the price for compact fluorescent lamp prices is much lower today than was the case five or ten years ago. An updated study would need to consider the range of efficiency technologies and practices available today or reasonably expected to be available in the coming year.

- Energy prices have risen significantly since the CEF study, which increases the number of energy efficiency technologies that are cost-effective, thus expanding the conservation potential.

- For the residential gas end uses, the New York study is only a rough approximation of savings potential across the country. A national study that includes all relevant 
technologies (including shell retrofits for both residential and commercial buildings) is needed.

- The effect of the Energy Independence and Security Act of 2007 (EISA 2007) is considered part of the remaining efficiency potential in this study, not included in the baseline. This assumption probably has the largest effect on the lighting end use, because EISA 2007 contains aggressive provisions for lighting efficiency. An updated study would need to incorporate this into the baseline.

This study did not consider the policies that would be needed to achieve these efficiency potentials, so should be considered a hypothetical, rather than practical, estimate of savings potential. Studies, such as CEF, that estimate achievable potential generally find that one-half to two-thirds of the economic potential is actually achievable with aggressive policies.

The results of this analysis are point estimates of savings potential, which ignore uncertainty about how energy use in the building sector will evolve during the next $20+$ years. Some of the major areas of uncertainty include energy prices, availability and price of efficiency technologies, and changes in consumer behavior. Using either scenario analysis or uncertainty analysis, it would be useful to estimate ranges or probability distributions of future savings potential.

Efficiency potential studies such as CEF and the New York state study are highly aggregated analyses that tend to ignore the great variability in the building stock (along dimensions such as climate, building configuration, equipment ownership, building occupancy and usage, etc.). Future studies should be conducted at a greater level of disaggregation to address variability in the building stock. One approach is to develop efficiency supply curves at the building level, possibly using the EIA building surveys (RECS and CBECS), which can then be aggregated to assess savings potential by building type, region, technology type, etc. Griffith and Crawley (2006) present a methodology for doing this type of building-level analysis for new commercial buildings.

\section{Conclusion}

This paper presents an estimate of the potential for energy efficiency improvements in the U.S. building sector by 2030 . The output of the study is a techno-economic potential for energy savings, which includes cost-effectiveness criteria but ignores the effect of policy implementation. The analysis uses the Energy Information Administration's AEO 2007 Reference Case as a business-as-usual (BAU) scenario, and applies percentage savings estimates by end use drawn from several prior efficiency potential studies. These prior studies include the U.S. Department of Energy's Scenarios for a Clean Energy Future (CEF) study and a recent study of natural gas savings potential in New York state. For a few end uses for which savings estimates are not readily available, we compiled technical data to estimate savings percentages and costs of conserved energy. The analysis shows that for electricity use in buildings, approximately one-third of the BAU consumption can be saved at a cost of conserved energy of $2.7 \notin / \mathrm{kWh}$ (all values in 2007 dollars), while for natural gas approximately the same percentage savings is possible at a cost of between 2.5 and $6.9 \$$ million Btu ( 2.4 to $6.6 \$ / G J)$. This costeffective level of savings results in national annual energy bill savings in 2030 of nearly $\$ 170$ 
billion. To achieve these savings, the cumulative capital investment needed between 2010 and 2030 is about $\$ 440$ billion, which translates to a 2-1/2 year simple payback period, or savings over the life of the measures that are nearly 3.5 times larger than the investment required (i.e., a benefit-cost ratio of 3.5). 


\section{References}

1e. 2008. Frequently Asked Questions from 1e Sales Support. http://www.1e.com/Support/faq.aspx (accessed April, 2008).

Arthur D. Little Inc. 1993. Characterization of Commercial Building Appliances. Prepared for the Building Equipment Division, Office of Building Technologies, U.S. Department of Energy. August.

Arthur D. Little Inc. 1999. Opportunities for Energy Savings in the Residential and Commercial Sectors with High-Efficiency Electric Motors: Final Report. Prepared for the U.S. Department of Energy. Reference 35495-14. December 1. http://www.eere.energy.gov/buildings/info/documents/pdfs/doemotor2 2 00.pdf.

BEA. 2008. Implicit Price Deflators for Gross Domestic Product

[online]. Bureau of Economic Analysis, U.S. Department of Commerce. February. http://www.bea.gov/national/index.htm (accessed 5 March, 2008).

CEE. 2008. CEE-AHRI HVAC Directory. Consortium for Energy Efficiency / Air-Conditioning, Heating, and Refrigeration Institute. September.

Creyts, Jon, Anton Derkach, Scott Nyquist, Ken Ostrowski, and Jack Stephenson. 2007. Reducing U.S. Greenhouse Gas Emissions: How Much at What Cost. McKinsey \& Company. December. http://www.mckinsey.com/clientservice/ccsi/pdf/US_ghg_final_report.pdf.

CSCI. 2007. Climate Savers Computing Initiative White Paper. Climate Savers Computing Initiative. November 30. http://www.climatesaverscomputing.org/media/whitepaper11302007.pdf.

FEMP. 2007. FEMP Designated Product: Commercial Steam Cookers. Washington, DC: US Department of Energy, Federal Energy Management Program. April. http://www1.eere.energy.gov/femp/pdfs/pseep steamcookers.pdf.

FSTC. 2002. Commercial Cooking Appliance Technology Assessment. San Ramon, CA: Food Service Technology Center. FSTC Report \# 5011.02.26. http://www.fishnick.com/equipment/techassessment/Appliance Tech_Assessment.pdf.

FSTC. 2008. Gas Combination Oven Life-Cycle Cost Calculator. Food Service Technology Center. http://www.fishnick.com/saveenergy/tools/calculators/gcombicalc.php (accessed September, 2008).

Griffith, B., and D. Crawley. 2006. Methodology for Analyzing the Technical Potential for Energy Performance in the U.S. Commercial Buildings Sector with Detailed Energy Modeling: Preprint. Golden, CO: National Renewable Energy Laboratory. NREL/CP550-40124. November. www.osti.gov/servlets/purl/895700-XfqU1C/

Interlaboratory Working Group on Energy-Efficient and Clean-Energy Technologies. 2000. Scenarios for a Clean Energy Future. Oak Ridge, TN and Berkeley, CA: Oak Ridge National Laboratory and Lawrence Berkeley National Laboratory. ORNL/CON-476 and LBNL-44029. November. http://www.ornl.gov/sci/eere/cef/.

Koomey, Jonathan G., Carrie A. Webber, Celina S. Atkinson, and Andrew Nicholls. 2001. Addressing Energy-Related Challenges for the U.S. Buildings Sector: Results from the Clean Energy Futures Study. Energy Policy. vol. 29, no. 14, pp. 1209-1222 (also LBNL47356). November. 
Mosenthal, Philip, R. Neal Elliott, Dan York, Chris Neme, Paul Chernick, and Kevin Petak. 2006. Natural Gas Energy Efficiency Resource Development Potential In New York. New York State Energy Research and Development Authority (NYSERDA). October 31. http://www.nyserda.org/publications/Final\%20Statewide $\% 20$ Natural $\% 20$ Gas $\% 20$ Efficie ncy $\% 20$ Potential $\% 20$ Study.pdf.

Rosenquist, Greg, Michael McNeil, Maithili Iyer, Steve Meyers, and Jim McMahon. 2004. Energy Efficiency Standards and Codes for Residential/Commercial Equipment and Buildings: Additional Opportunities. Berkeley, CA: Lawrence Berkeley National Laboratory, prepared for the National Commission on Energy Policy. LBID-2533. July.

Roth, Kurt, Gerald Larocque, and Jonathan Kleinman. 2004. Energy Consumption by Office and Telecommunications Equipment in Commercial Buildings--Volume II: Energy Savings Potential. Cambridge, MA: Prepared by TIAX LLC for the U.S. Department of Energy. TIAX Reference no. D0065-11.08. December. http://www.eere.energy.gov/buildings/info/publications.html.

Roth, Kurt, K. McKenney, R. Ponoum, and C. Paetsch. 2007. Residential Miscellaneous Electric Loads: Energy Consumption Characterization and Savings Potential. Cambridge, MA: TIAX LLC. TIAX Reference No. D0370. July.

US DOE. 1998. Annual Energy Outlook 1999, with Projections to 2020. Washington, DC: Energy Information Administration, U.S. Department of Energy. DOE/EIA-0383(99). December.

US DOE. 2007a. 2007 Buildings Energy Databook. Washington, DC: U.S. Department of Energy, Office of Energy Efficiency and Renewable Energy. September. http://buildingsdatabook.eere.energy.gov/.

US DOE. 2007b. Annual Energy Outlook 2007, with Projections to 2030. Washington, DC: Energy Information Administration, U.S. Department of Energy. DOE/EIA-0383(2007). February. http://www.eia.doe.gov/oiaf/aeo/pdf/0383(2007).pdf.

US DOE. 2007c. Annual Energy Review 2006. Washington, DC: Energy Information Administration, U.S. Department of Energy. DOE/EIA-0384(2006). June. http://www.eia.doe.gov/emeu/aer/pdf/aer.pdf.

US DOE. 2007d. Technical Support Document: Energy Efficiency Program for Consumer Products: Energy Conservation Standards for Residential Furnaces and Boilers. Washington, DC: U.S. Department of Energy, Assistant Secretary, Office of Energy Efficiency and Renewable Energy, Building Technologies Program. September. http://www.eere.energy.gov/buildings/appliance standards/residential/fb tsd 0907.html.

US DOE. 2008. Monthly Energy Review, April 2008. Washington, DC: Energy Information Administration, U.S. Department of Energy. DOE/EIA-0035(2008/04). April. http://www.eia.doe.gov/emeu/mer/pdf/mer.pdf.

US EPA. 2004. ENERGY STAR Gas Steam Cooker Savings Calculator [spreadsheet]. United States Environmental Protection Agency. September. http://energystar.gov/ia/business/bulk_purchasing/bpsavings_calc/Gas_Steam_Cooker_0 90204.xls (accessed September, 2008).

US EPA. 2007a. ENERGY STAR Copier Savings Calculator [spreadsheet]. United States Environmental Protection Agency. July. http://www.energystar.gov/ia/business/bulk_purchasing/bpsavings_calc/Calc_copiers.xls (accessed April, 2008). 
US EPA. 2007b. Putting Energy into Profits: ENERGY STAR Guide for Restaurants. Washington, DC: U.S. Environmental Protection Agency. May. http://www.energystar.gov/ia/business/small business/restaurants guide.pdf.

US EPA. 2008a. ENERGY STAR Computer Savings Calculator [spreadsheet]. United States Environmental Protection Agency. February. http://www.energystar.gov/ia/business/bulk_purchasing/bpsavings_calc/Calc_computers. xls (accessed April, 2008).

US EPA. 2008b. ENERGY STAR Dishwasher Savings Calculator [spreadsheet]. United States Environmental Protection Agency. February. http://www.energystar.gov/ia/business/bulk_purchasing/bpsavings_calc/CalculatorComm ercialDishwasher.xls (accessed April, 2008).

US EPA. 2008c. ENERGY STAR Electric Fryer Savings Calculator [spreadsheet]. United States Environmental Protection Agency. January. http://www.energystar.gov/ia/business/bulk_purchasing/bpsavings_calc/Commercial_Ele ctric Fryers Bulk.xls (accessed April, 2008).

US EPA. 2008d. ENERGY STAR Gas Fryer Savings Calculator [spreadsheet]. United States Environmental Protection Agency. January. http://www.energystar.gov/ia/business/bulk_purchasing/bpsavings_calc/Commercial_Gas Fryers Bulk.xls (accessed April, 2008).

US EPA. 2008e. ENERGY STAR Hot Food Holding Cabinet Savings Calculator [spreadsheet]. United States Environmental Protection Agency. January. http://www.energystar.gov/ia/business/bulk_purchasing/bpsavings_calc/CalculatorHotFo odHoldingCabinetBulk.xls (accessed April, 2008).

US EPA. 2008f. ENERGY STAR Monitor Savings Calculator [spreadsheet]. United States Environmental Protection Agency. January. http://www.energystar.gov/ia/business/bulk_purchasing/bpsavings_calc/Calc_monitors.xl $\underline{\text { s }}$ (accessed April, 2008).

US EPA. 2008g. ENERGY STAR Printers, Scanners, and All-in-ones. http://www.energystar.gov/index.cfm?fuseaction=find_a product.showProductGroup\&p gw_code=PS (accessed April, 2008). 


\section{Appendix A: Comparison of AEO 1999 and AEO 2007 End Use Efficiency Assumptions}

For a few key end uses that have undergone significant changes in efficiency since the publication of the original CEF study (based on the 1999 AEO), we examine whether the efficiency levels in the AEO reference cases changed significantly. For example, we know that the residential cooling baseline has changed significantly due to new (post-1999) Federal efficiency standards for central air conditioners. We compared the underlying end-use efficiency forecasts output by the NEMS model in the course of producing the 1999 and 2007 AEOs. ${ }^{7}$ Figure A-1 shows this comparison between the AEO reference case efficiencies for residential central air conditioning, and indicates an approximately 15\% improvement in efficiency between the two AEO forecasts (primarily due to the new standards). As discussed in the main body of this report, this difference in AEO baselines is counterbalanced by new efficiency technologies that have been introduced since 1999 for this end use, resulting in roughly the same savings potential.

Figure A-2 shows a similar comparison for an end use (commercial cooling) that did not change much between the two AEO forecasts. Most end uses are similar to this one (i.e., little efficiency improvement in AEO 2007 vs. 1999). Figures A-3 through A-12 offer similar comparisons for other major residential and commercial end uses. Note that residential heat pump heating (Figure A-4) also shows significant efficiency improvement since the 1999 AEO, again due to minimum Federal efficiency standards. The same technology trends that affect central air conditioning, however, also affect this end use, so the savings potential is not significantly affected by this improvement in baseline efficiency. Figure A-10 shows higher efficiencies in the 2007 forecast for commercial hot water heaters, an effect of increasing market penetration of condensing commercial water heaters due to higher natural gas prices. For three of the end uses - residential thermal shell, commercial lighting, and ventilation - the efficiency metric used in the AEO differs between the 1999 and 2007 versions, so we present efficiency values indexed to the base year.

Reviewing all these end uses, we believe that the 1999 and 2007 AEO forecasts do not have significantly different assumptions at the detailed technology level (with the exception of central air conditioners and heat pumps, which have already been discussed).

\footnotetext{
${ }^{7}$ The data shown in this appendix are drawn from the Supplemental tables for the AEO reference case, available on the AEO web site: http://www.eia.doe.gov/oiaf/aeo/index.html. The 1999 data are from: http://www.eia.doe.gov/oiaf/archive/aeo99/homepage.html.
} 
Figure A-1: Residential Cooling, Central Air Conditioning Efficiency Trends

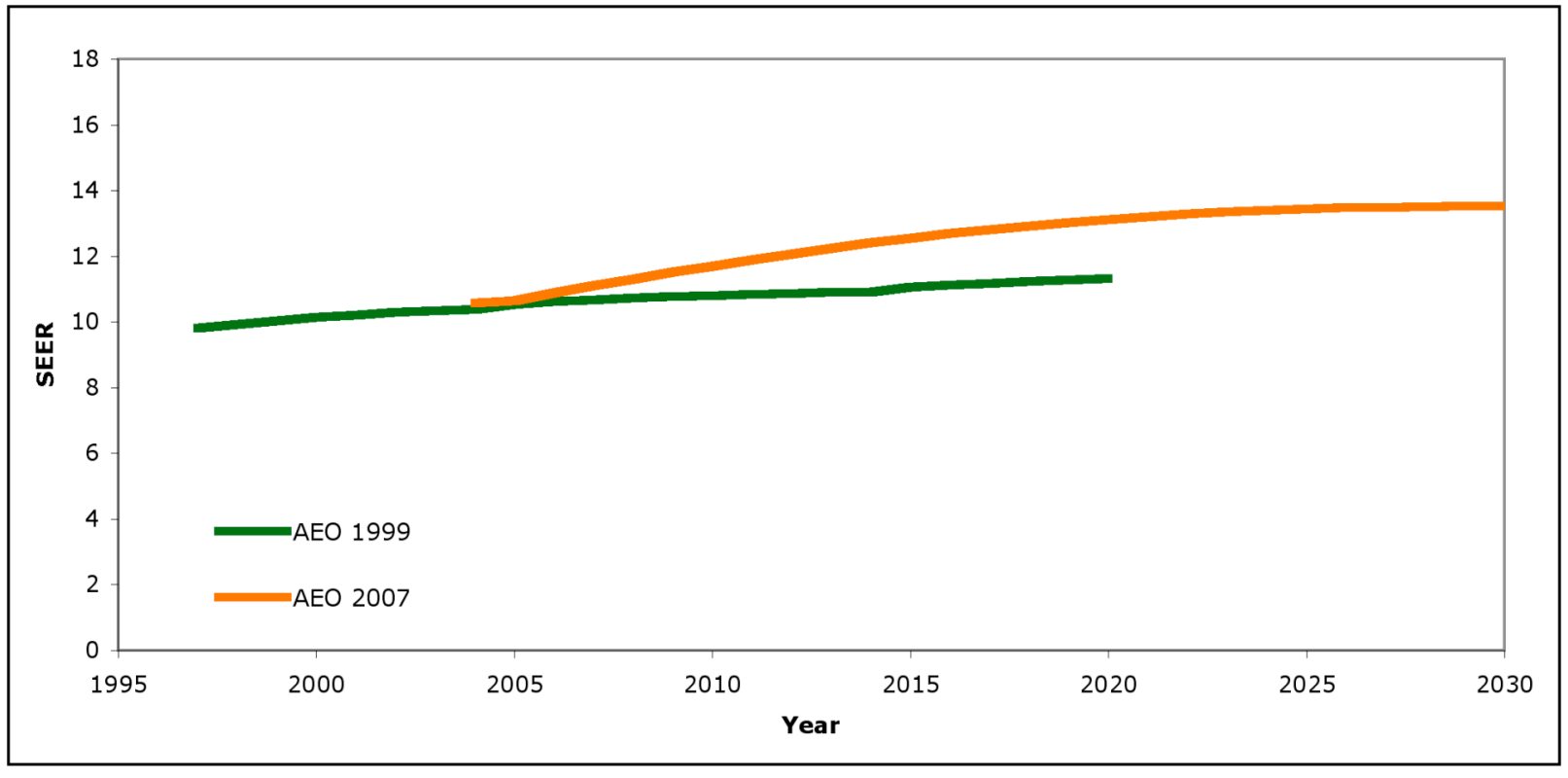

Figure A-2: Commercial Electric Cooling Efficiency Trends

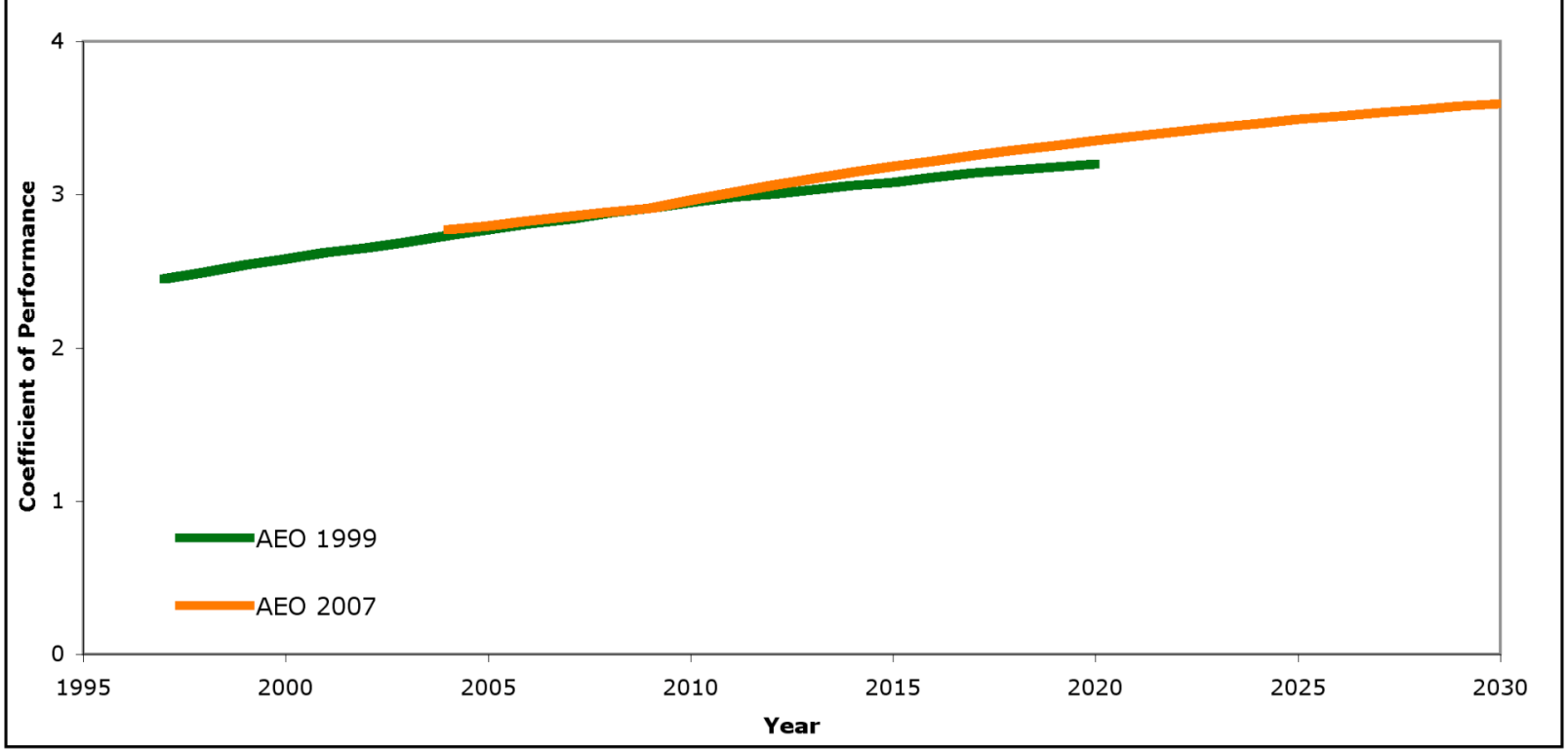


Figure A-3: Residential Heating, Natural Gas Furnace Efficiency Trends

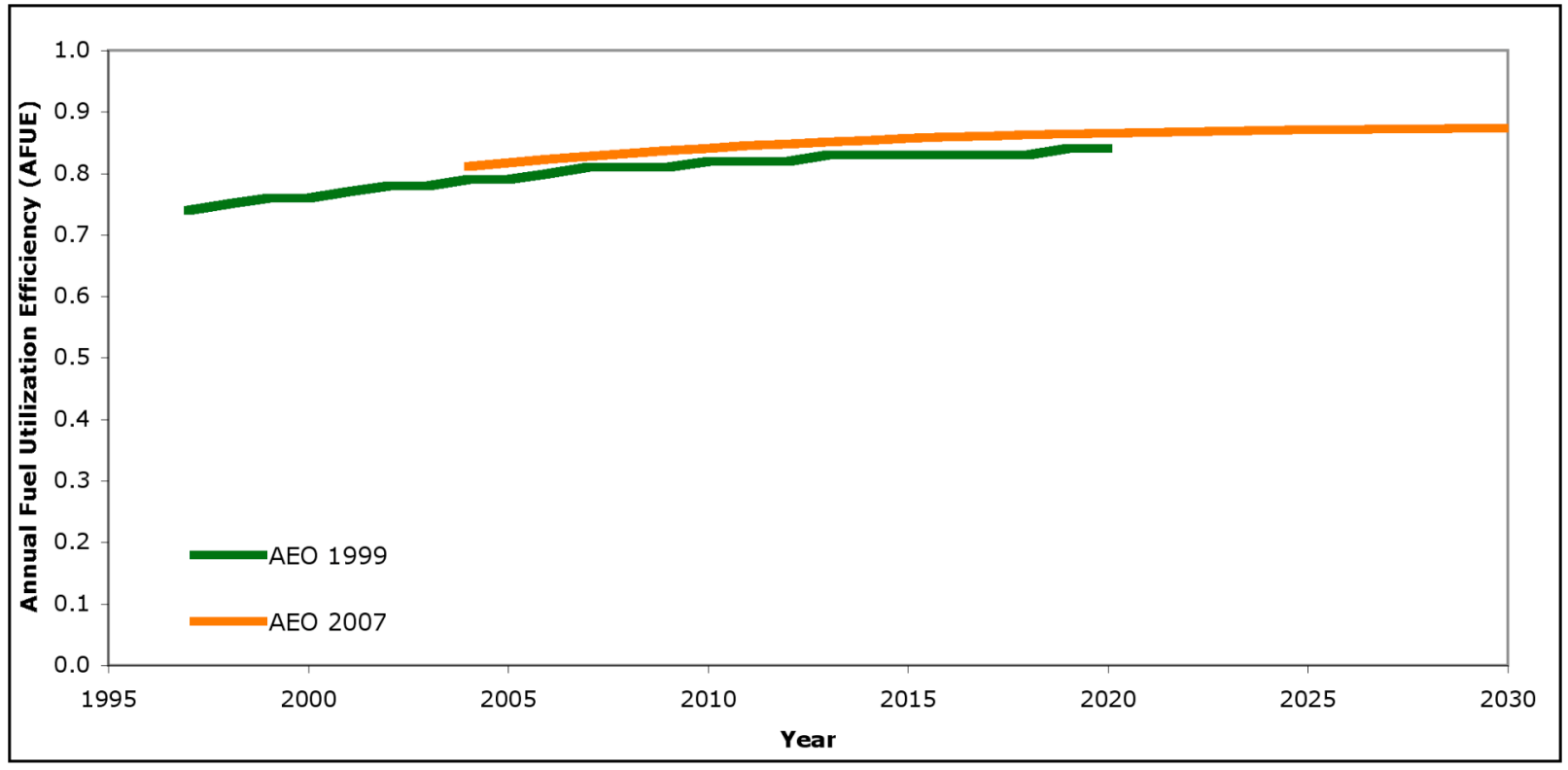

Figure A-4: Residential Heating, Electric Heat Pump Efficiency Trends

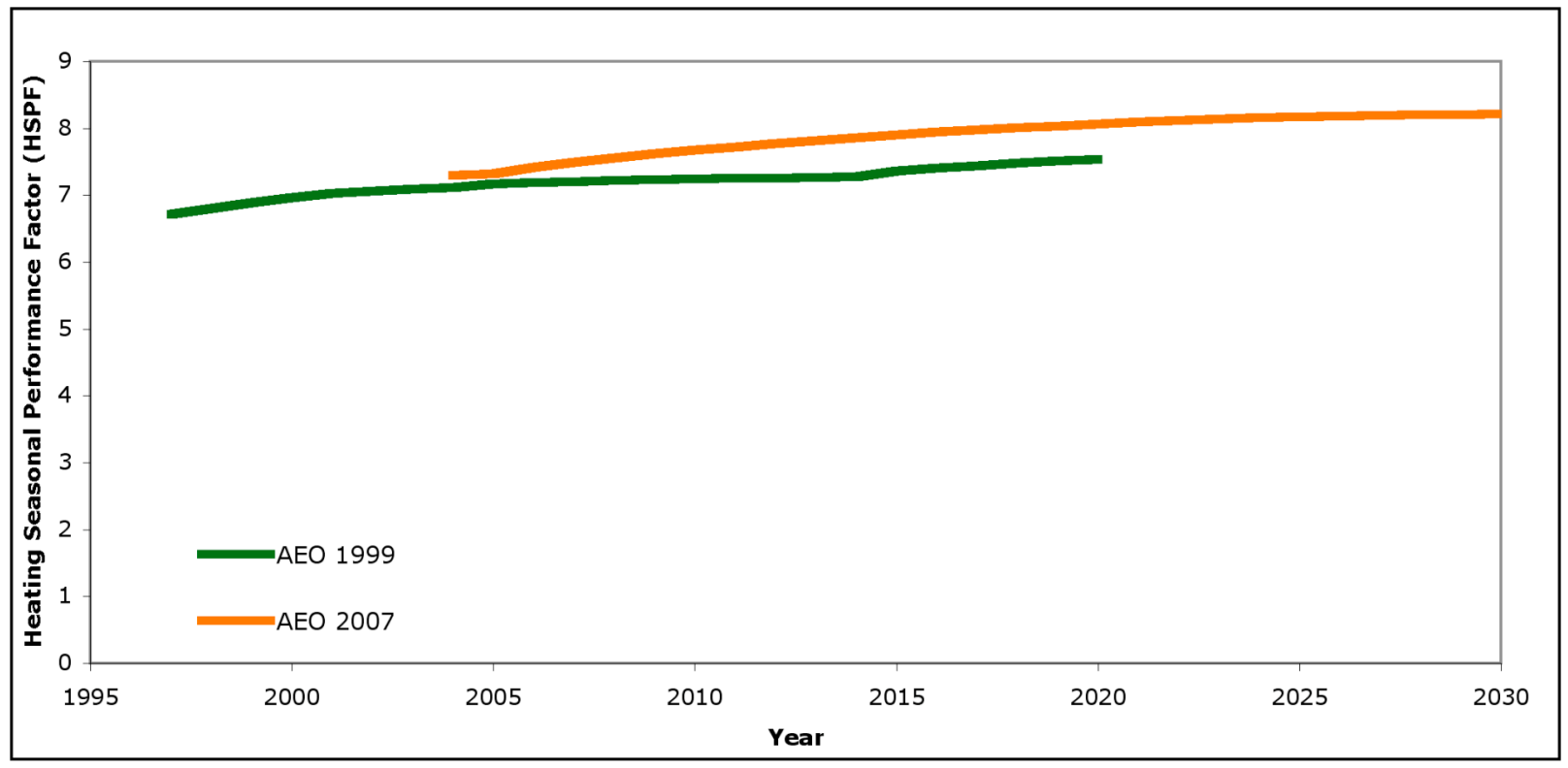


Figure A-5: Residential Natural Gas Water Heating Efficiency Trends

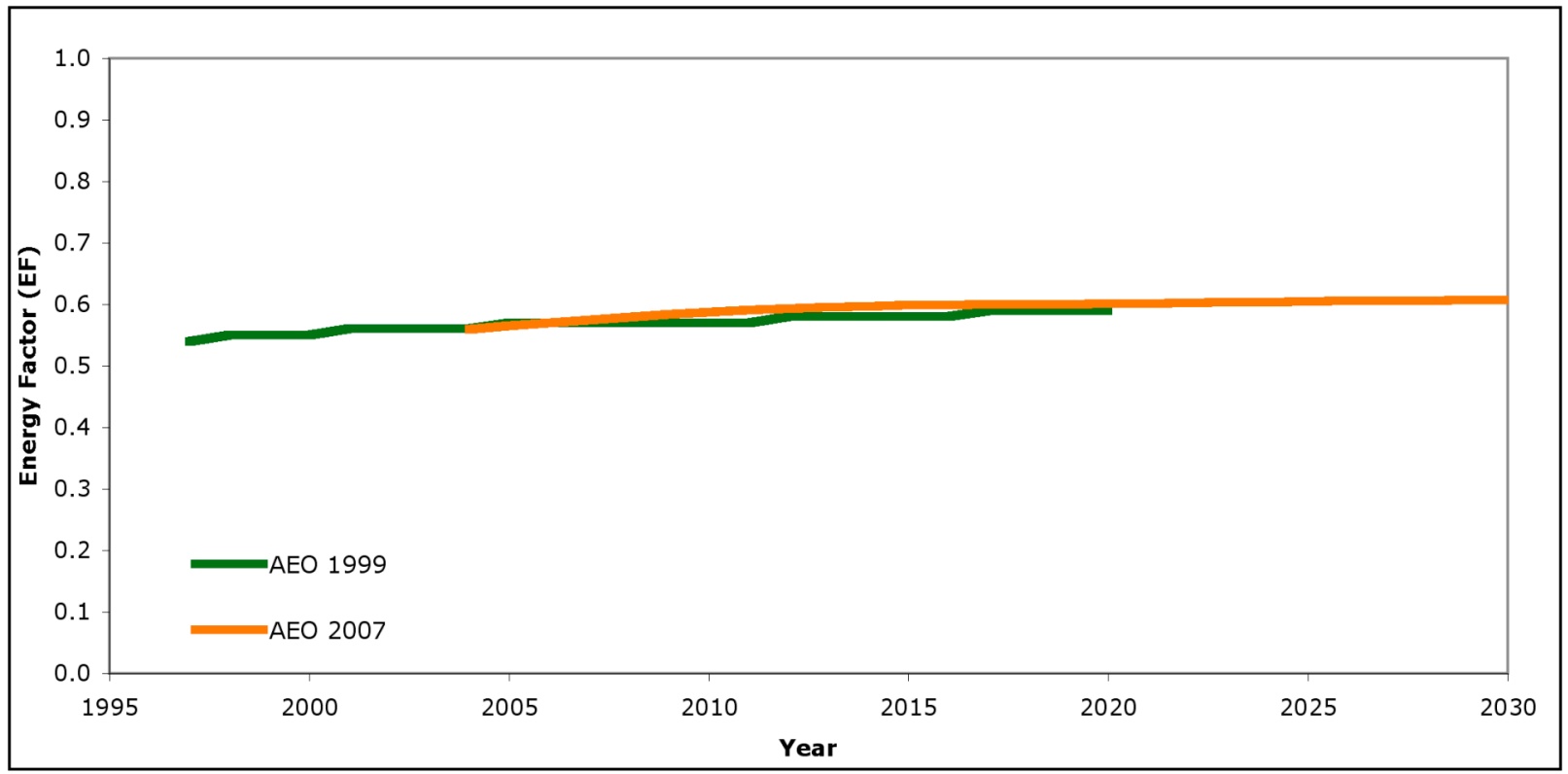

Figure A-6: Residential Refrigerator Efficiency Trends

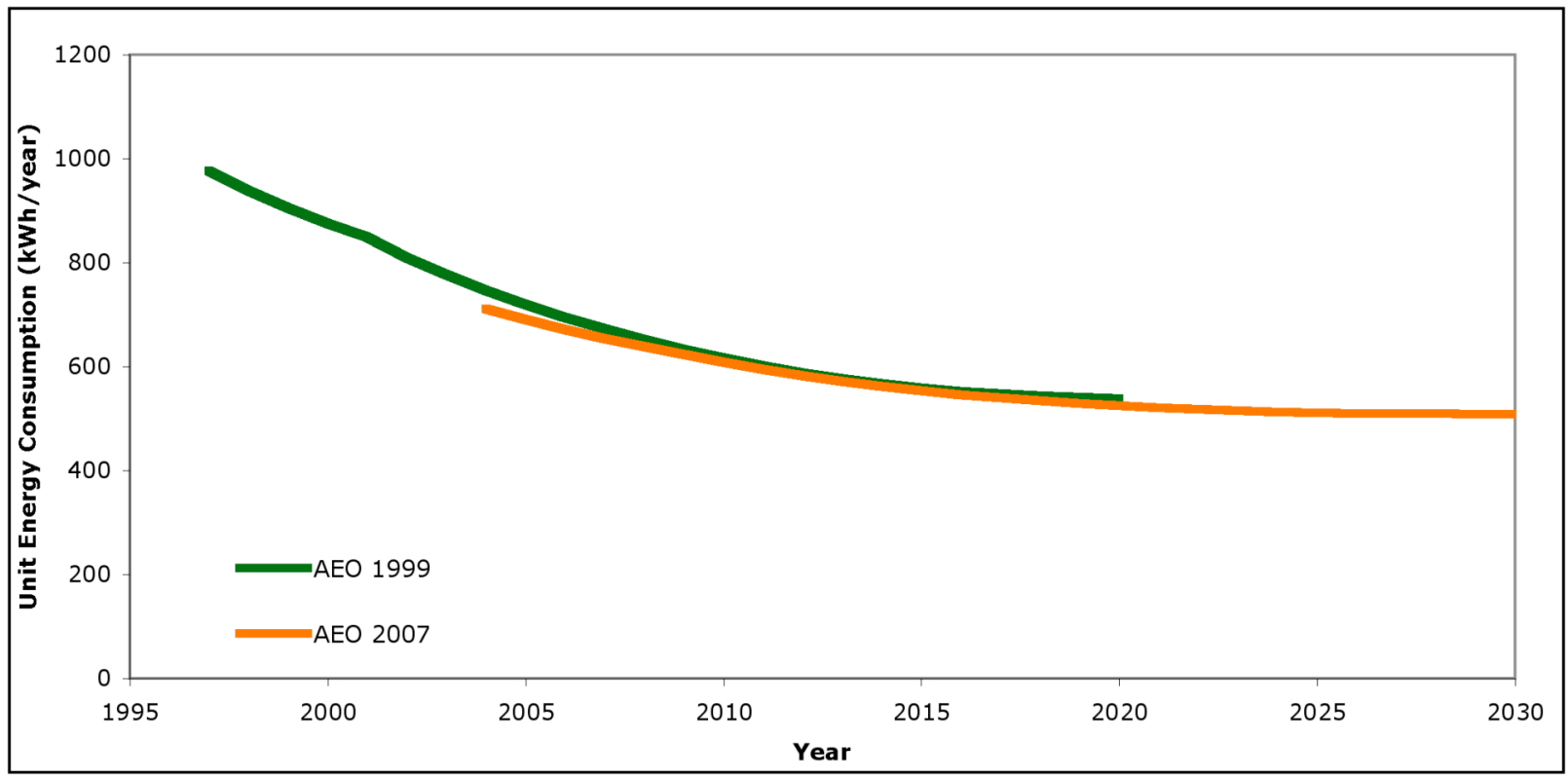


Figure A-7: Residential Thermal Shell (Heating) Efficiency Index Trends

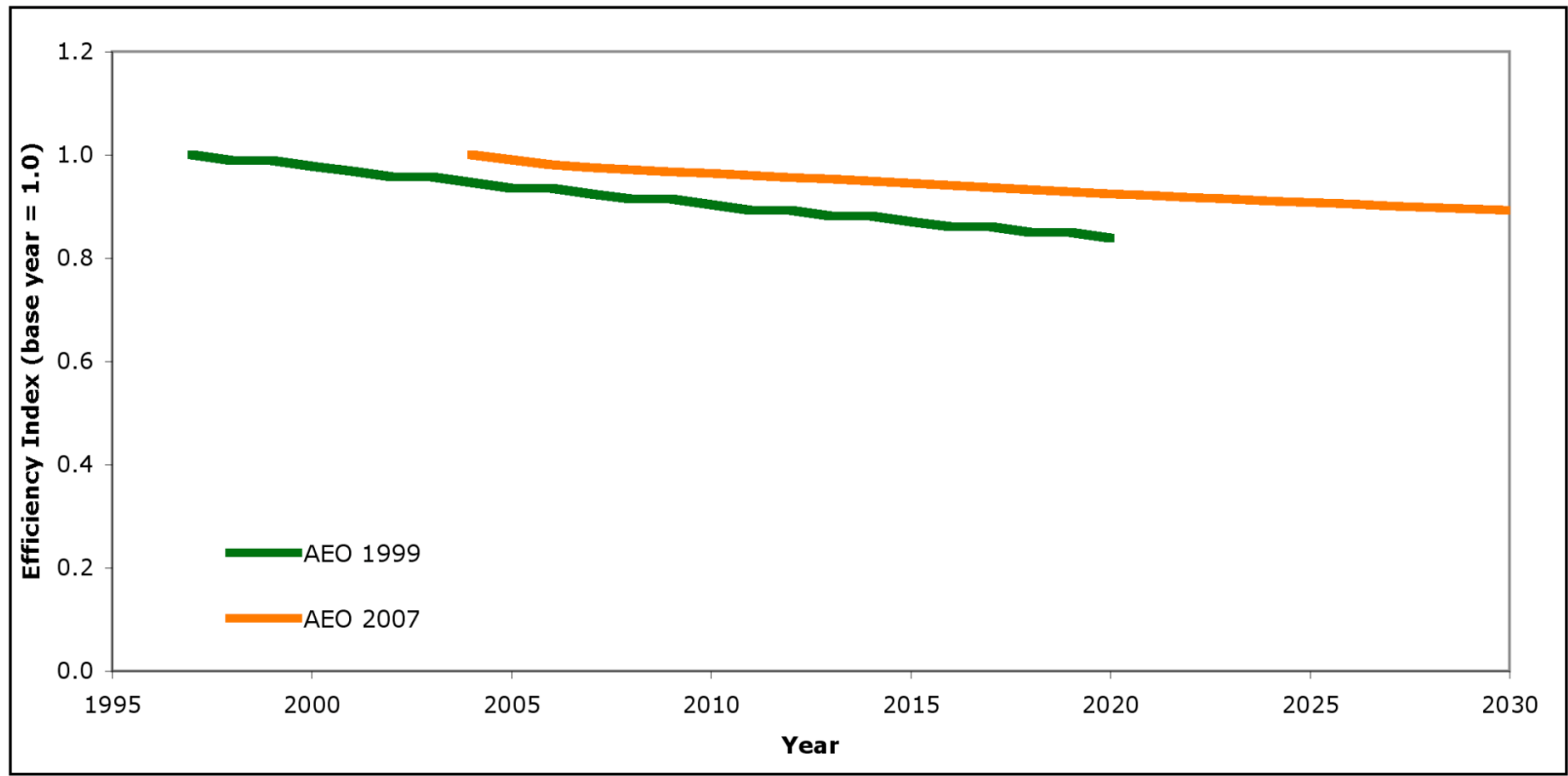

Figure A-8: Commercial Electric Heat Pump Heating Efficiency Trends

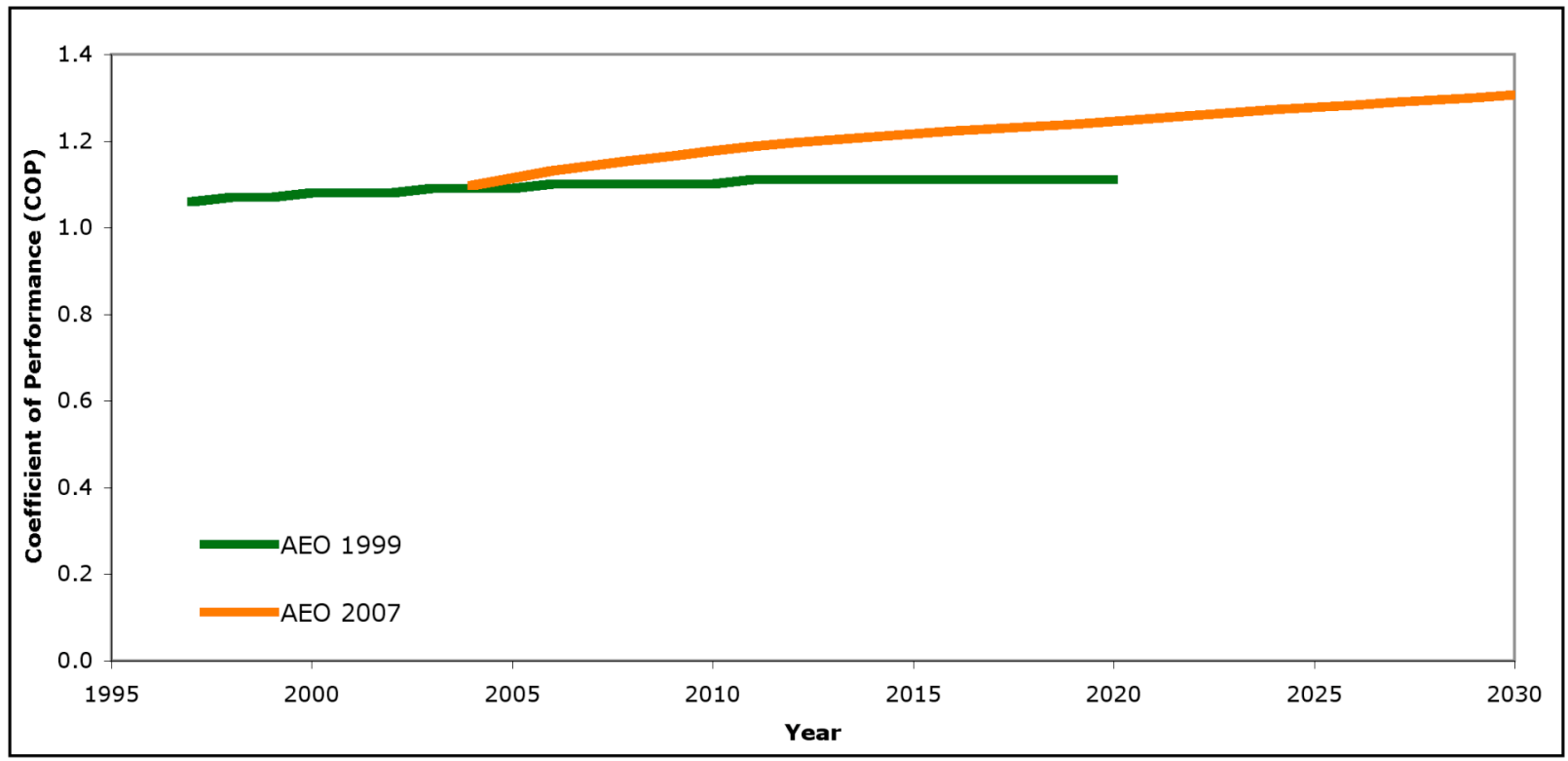


Figure A-9: Commercial Natural Gas Heating Efficiency Trends

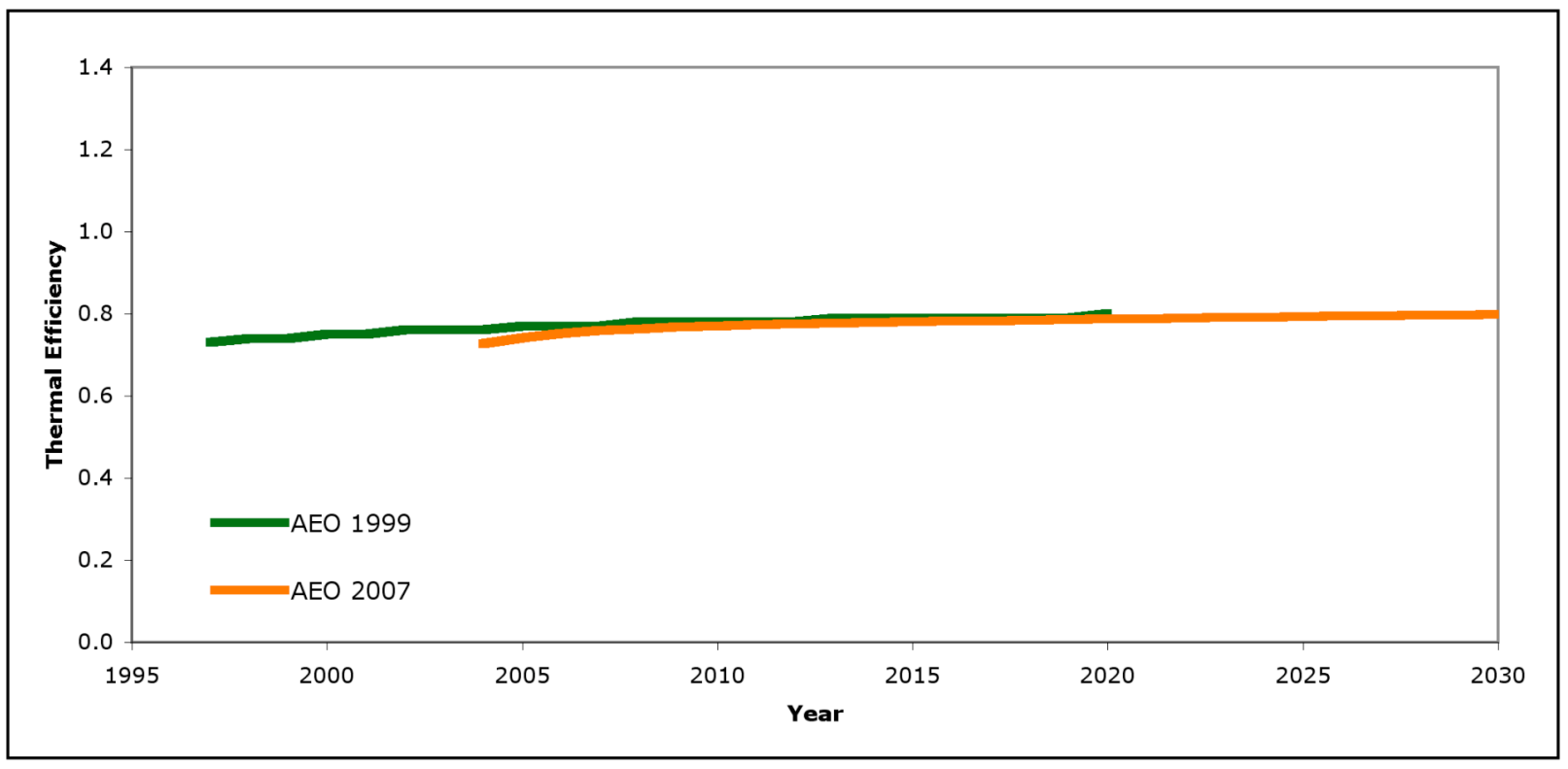

Figure A-10: Commercial Natural Gas Water Heating Efficiency Trends

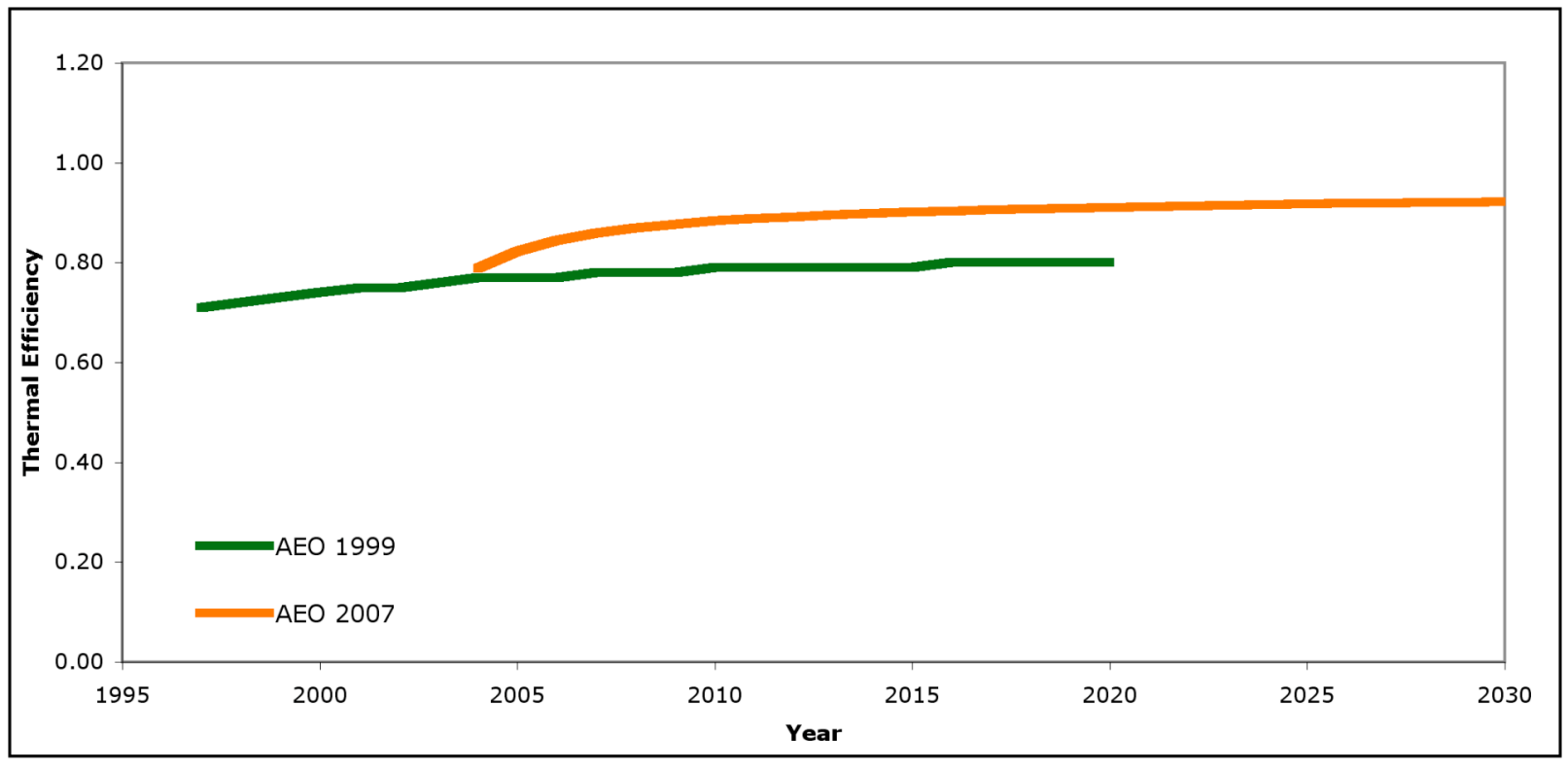


Figure A-11: Commercial Lighting Efficacy Trends

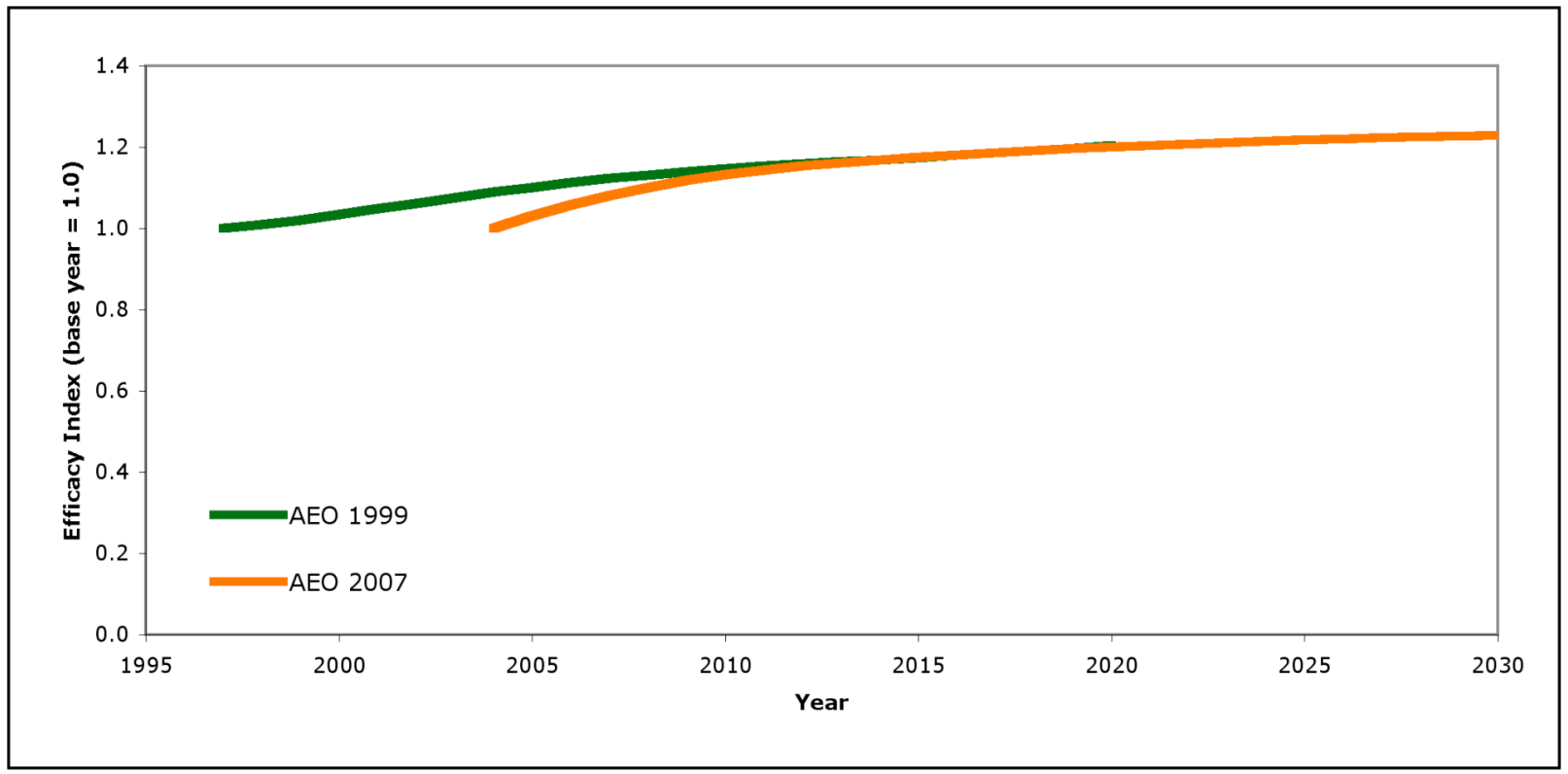

Figure A-12: Commercial Ventilation Efficiency Trends

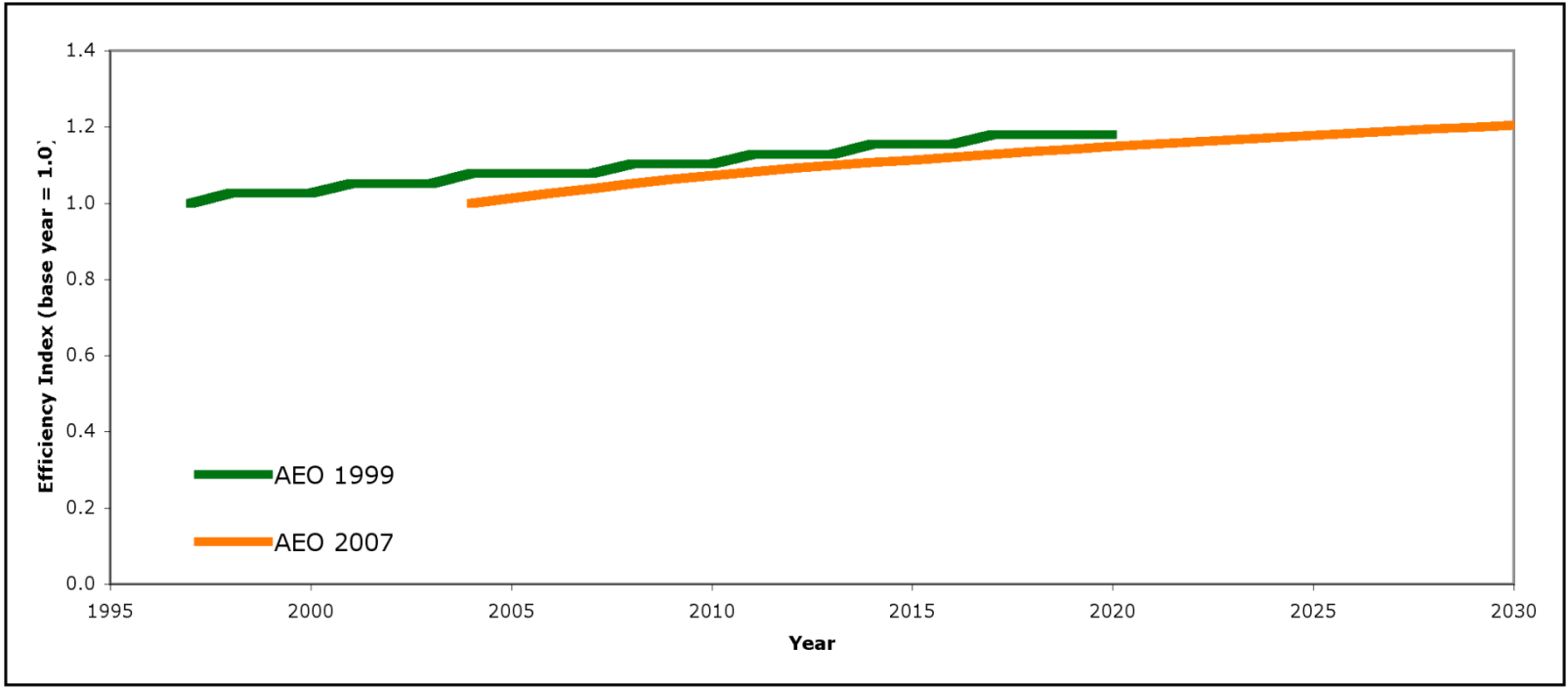

